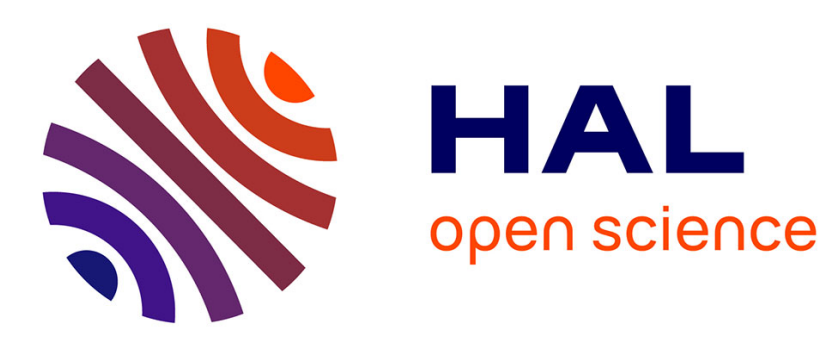

\title{
Modes, tempo, and spatial variability of Cenozoic cratonic denudation: The West African example Anicet Beauvais, Dominique Chardon
}

\section{To cite this version:}

Anicet Beauvais, Dominique Chardon. Modes, tempo, and spatial variability of Cenozoic cratonic denudation: The West African example. Geochemistry, Geophysics, Geosystems, 2013, 14, pp.1590 1608. 10.1002/ggge.20093 . hal-01097294

\section{HAL Id: hal-01097294 \\ https://hal.science/hal-01097294}

Submitted on 20 Dec 2016

HAL is a multi-disciplinary open access archive for the deposit and dissemination of scientific research documents, whether they are published or not. The documents may come from teaching and research institutions in France or abroad, or from public or private research centers.
L'archive ouverte pluridisciplinaire HAL, est destinée au dépôt et à la diffusion de documents scientifiques de niveau recherche, publiés ou non, émanant des établissements d'enseignement et de recherche français ou étrangers, des laboratoires publics ou privés. 

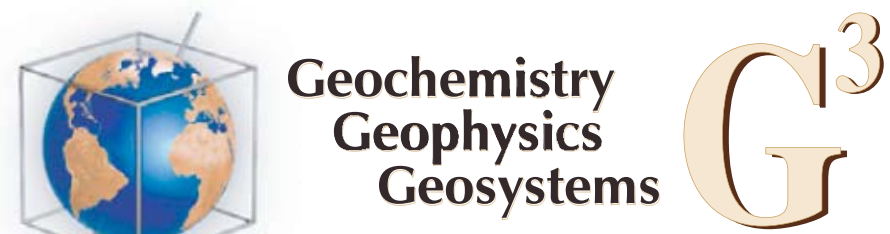

\title{
Modes, tempo, and spatial variability of Cenozoic cratonic denudation: The West African example
}

\author{
Anicet Beauvais \\ Aix Marseille Université, IRD, CNRS, CEREGE UM34, France, BP \\ 80, 13545, Aix-en-Provence Cedex 4, France (beauvais@cerege.fr) \\ Dominique Chardon \\ Université de Toulouse, UPS (OMP), GET, Toulouse, France \\ CNRS, GET, Toulouse, France \\ IRD, GET, Toulouse, France
}

[1] Quantifying long-term erosion of tropical shields is crucial to constraining the role of lateritic regolith covers as prominent sinks and sources of $\mathrm{CO}_{2}$ and sediments in the context of long-term Cenozoic climate change. It is also a key to understanding long-term landform evolution processes operating over most of the continental surface and their control onto the sediment routing system. We study the surface evolution of West Africa over three erosion periods $(\sim 45-24, \sim 24-11$ and $\sim 11-0 \mathrm{Ma})$ recorded by relicts of three subcontinental-scale lateritic paleolandsurfaces whose age is bracketed by ${ }^{39} \mathrm{Ar} /{ }^{40} \mathrm{Ar}$ dating of lateritic K-Mn oxides. Denudation depths and rates compiled from 380 field stations show that despite heterogeneities confined to early-inherited reliefs, the subregion underwent low and homogeneous denudation $\left(\sim 2-20 \mathrm{~m} \mathrm{Ma}^{-1}\right)$ over most of its surface whatever the considered time interval. This homogeneity is further documented by a worldwide compilation of cratonic denudation rates, over long-term, intermediate and modern Cenozoic time scales $\left(10^{0}-10^{7} \mathrm{yr}\right)$. These results allow defining a steady state cratonic denudation regime that is weatheringlimited, i.e., controlled by the thickness of the (lateritic) regolith available for stripping. Steady state cratonic denudation regimes are enabled by maintained compartmentalization of the base levels between river knick points controlled by relief inheritance. Under such regimes, lowering of base levels and their fossilization are primarily imposed by long-term eustatic sea level fall and climate rather than by epeirogeny. The expression of steady state cratonic denudation regimes in clastic sedimentary fluxes remains to be investigated.

Components: 9,200 words, 13 figures, 2 tables.

Keywords: denudation; long-term landscape evolution; Craton; Cenozoic; Regolith; West Africa.

Index Terms: 1130 Geochronology: Geomorphological geochronology, 1625 Global change: Geomorphology and weathering $(0790,1824,1825,1826,1886), 8103$ Tectonophysics: Continental cratons, 9305 Geographic location: Africa, 9604 Information related to geologic time: Cenozoic.

Received 30 October 2012; Revised 6 February 2013; Accepted 8 February 2013; Published 21 May 2013.

Beauvais, A., and D. Chardon (2013) Modes, tempo, and spatial variability of Cenozoic cratonic denudation: The West African example, Geochem. Geophys. Geosyst., 14, 1590-1608, doi:10.1002/ggge.20093. 


\section{Introduction}

[2] Stable continental interiors (cratonic domains) are subjected to slow denudation. Given their very large areal extent, their surface exchanges with the atmosphere and their erosional delivery to the ocean are however significant. Of prime importance are the vast continental platforms of the tropical belt that supply very long segments of the world's passive margins such as those of Africa, Australia, Peninsular India, or Eastern South America. On geological time scales, warm and humid climate in cratonic contexts enhances efficient consumption of $\mathrm{CO}_{2}$ by intense rock weathering, exportation of soluble elements in rivers, and concomitant accumulation of thick lateritic regolith mantles. Climate change(s) toward increased seasonality may enable preferential stripping and exportation of previously stored regolith mantles [Fairbridge and Finkl, 1980]. Although essentially climatically controlled, the resulting clastic sediment supplies do not necessarily correlate with weathering fluxes and may not consistently reproduce the Cenozoic clastic sedimentation rate increases or pulses documented worldwide in higher latitude contexts [e.g., Bishop, 1985; Molnar, 2004]. On land, in situ quantification of long-term $\left(10^{6}-10^{8} \mathrm{yr}\right)$ denudation of tropical shields is therefore key to understanding these first-order temporary sinks or sources of
$\mathrm{CO}_{2}$ and sediments, and to evaluating their contribution to the global sedimentary and biogeochemical cycles in the context of Cenozoic climate cooling.

[3] As a consequence of their peculiar denudation mode, tropical shields typically preserve relict landscapes, some of which being inherited from pre-Cenozoic times. This preservation challenges the concept of steady state landscapes developed for active orogens, which may only apply to specific tectonically active contexts encompassing a very limited proportion of the continent's surface [Bishop, 2007]. Long-term erosion mechanisms of tropical shields therefore deserve particular attention to understand the long-term landform development processes operating or having operated over most of the continental surface and their consequences onto the sediment routing system.

[4] Relict elements of cratonic landscapes commonly carry remnant markers of former abandoned base levels. If dated, these markers may be useful to calibrate long-term incision or denudation rates that are generally averaged on regional scales from mean elevation differences between remnant markers [e.g., Bishop, 1985]. Here we use the exceptional geomorphic record of West Africa (Figure 1) to characterize an evolving large-scale $\left(10^{2}-10^{3} \mathrm{~km}\right)$ cratonic relief subjected to three

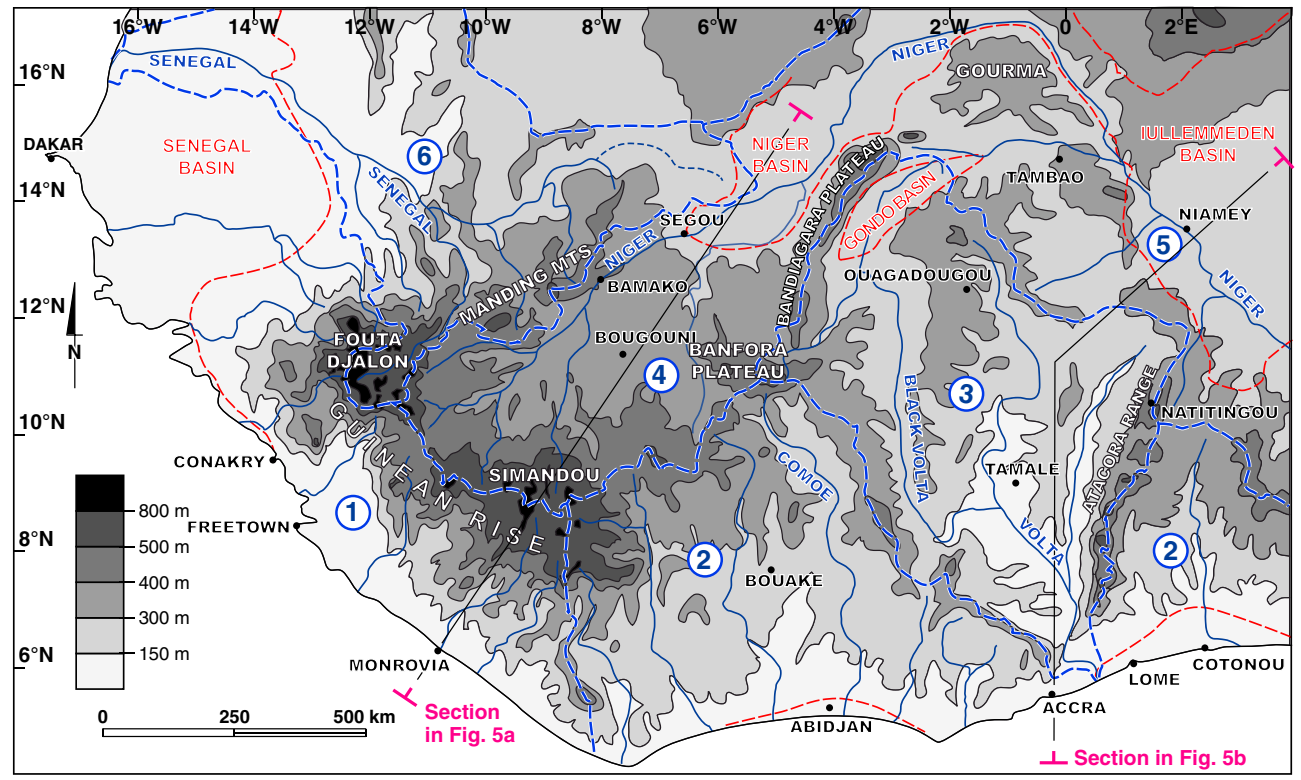

Figure 1. Topography and drainage of West Africa. Blue lines are rivers and dashed blue lines represent boundaries of subdrainage areas defined for the purpose of the analysis (data for these subdrainages are presented in Figures 9-12). 1 - Southwestern drainage of the Guinea rise; 2 - Southern drainage excluding the Volta watershed; 3 - Volta watershed; 4 - Upper Niger watershed; 5 - Lower Niger watershed; 6 - Upper Senegal watershed. The boundary between the Upper (4) and the lower Niger (5) catchment is taken at $2^{\circ} \mathrm{W}$. Dashed red lines indicate the boundaries of the Cenozoic sedimentary basins. 
erosion periods $(\sim 45-24, \sim 24-11$, and $\sim 11-0 \mathrm{Ma})$ recorded by relicts of three subcontinental-scale lateritic paleolandsurfaces, whose age is bracketed by ${ }^{39} \mathrm{Ar} /{ }^{40} \mathrm{Ar}$ dating of lateritic K-Mn oxides. Compilation of the elevation and incision of paleolandsurface relicts from 380 stations distributed over the subregion allows evaluating the space and time variability of denudation rates in relation to evolving relief and river catchments. Our results and a compilation of cratonic denudation rates obtained over various Cenozoic time scales document the low and homogeneous denudation $\left(\sim 2-20 \mathrm{~m} \mathrm{Ma}^{-1}\right)$ of cratonic surfaces. These results are used to define a weathering-limited steady state cratonic denudation regime primarily driven by long-term eustatic sea level fall and climate change and maintained by compartmentalization of the base levels between river knick points controlled by relief inheritance.

\section{Denudation Chronology of West Africa}

[5] In West Africa, Paleogene greenhouse climate sustained lateritic weathering that formed thick kaolinitic regoliths and bauxites on an old, continental-scale, low-relief erosion surface called the African Surface [Boulangé and Millot, 1988; Chardon et al., 2006; Burke and Gunnell, 2008]. Post-Eocene seasonally wet/dry climate favoring chemical weathering was interrupted by periods of seasonally drier climate propitious to mechanical erosion [e.g., Séranne, 1999]. Such climatic variations have shaped a sequence of stepped lateritic paleolandsurfaces marking successive denudation stages of the African surface [Michel, 1973; Grandin, 1976; Burke and Gunnell, 2008; Figure 2a].

[6] Each paleolandsurface in the sequence, including the African surface, has a type geomorphic, petrological, and geochemical signature (Boulet [1970], Eschenbrenner and Grandin [1970], Grandin [1976], synthesis in Tardy and Roquin [1998]). Thick, in situ formed weathering mantles underlie the African surface, $\mathrm{S}_{1}$, and the so-called Intermediate surface, $S_{2} . S_{1}$ relicts are bauxite duricrust-capped mesas making regional summits. Relicts of the $S_{2}$ paleolandsurfaces are capped by a thick ferricrete. The lower surfaces in the sequence are three pediments (glacis in the French literature; Figure 2a), called the high $\left(\mathrm{S}_{3}\right)$, middle $\left(\mathrm{S}_{4}\right)$, and low $\left(\mathrm{S}_{5}\right)$ glacis. The glacis are characterized by composite weathering mantles, which affect the truncated bedrock or the preexisting weathering profile underlying their erosion surface, and the pediment material overlying that surface. Relicts of the high and middle glacis are commonly sealed by a ferricrete.

[7] $S_{1}$ weathering profile formed on any type of pre-Eocene rock in West Africa and did not develop on early to mid-Eocene marine sediments marking the last intracratonic transgression. Post mid-Eocene fluvial sediments of the Continental Terminal overlie $S_{1}$ laterites in the intracratonic basins [Lang et al., 1986]. The $\mathrm{S}_{2}$ surface and the subsequent glacis developed on the Continental Terminal and on any rock type of its substrate [e.g., Beaudet et al., 1977]. $\mathrm{S}_{1}$ was therefore functional until the end of the mid-Eocene, whereas $\mathrm{S}_{2}, \mathrm{~S}_{3}, \mathrm{~S}_{4}$, and $\mathrm{S}_{5}$ established during the Oligocene and the Neogene.

[8] The Tambao supergene $\mathrm{Mn}$ ore deposit in Northern Burkina Faso (Figure 1) is leveled by $\mathrm{S}_{2}$ and $\mathrm{S}_{3}$, and its piedmont is shaped by $\mathrm{S}_{4}$ and $\mathrm{S}_{5}$ [Grandin, 1976]. Radiometric ${ }^{39} \mathrm{Ar}^{40} \mathrm{Ar}$ ages of supergene cryptomelane $\left(\mathrm{K}_{1-2} \mathrm{Mn}_{8} \mathrm{O}_{16}, \mathrm{nH}_{2} \mathrm{O}\right)$ were measured from surface and core samples taken at various elevations and depths spanning the altitudinal range of the paleolandsurfaces [Figure 2; see also Beauvais et al., 2008]. Five groups of ages are depicted, i.e., 59-45 Ma, 29-24 Ma, 18-11.5 Ma, 7.2-5.8 Ma, and 3.4-2.9 Ma, which bracket periods of enhanced chemical weathering that produced the type regoliths (weathering profile and ultimately its overlying duricrust) of the successive paleosurfaces (Figures $2 \mathrm{a}$ and $2 \mathrm{~b}$ ). The first weathering period (59-45 Ma) characterizes the downward growth of the bauxitic regolith accompanying the lowering of the topographic landsurface. During this period, the weathering front ultimately attained up to $40 \mathrm{~m}$ depth underneath the Tambao hilltop that is currently capped by the intermediate ferricrete (Figures 2a and $2 b$ ). This early weathering period is in agreement with the stratigraphic age of the bauxitic regolith reported above [Beauvais et al., 2008; see also Hénocque et al., 1998 and Colin et al., 2005], and corresponds to the early Tertiary Worldwide bauxite event [Prasad, 1983; see also Bardossy and Aleva, 1990]. The time intervals separating radiometric age groups, i.e., $\sim 45-29 \mathrm{Ma}, \sim 24-18 \mathrm{Ma}, \sim 11-7 \mathrm{Ma}$, $\sim 5-3 \mathrm{Ma}$ and $\sim 3-0 \mathrm{Ma}$ are interpreted as seasonally drier periods of limited weathering, which were propitious to the dissection of $S_{1}$ to $S_{5}$, respectively (Figures 2a and 2c). Between 29 and $24 \mathrm{Ma}$, regolith production took over dissection of the $\mathrm{S} 1$ bauxitic surface to form by weathering the $S_{2}$ intermediate surface. The intermediate ferricrete, as the end product of this weathering period, sealed the $\mathrm{S}_{2}$ surface up 

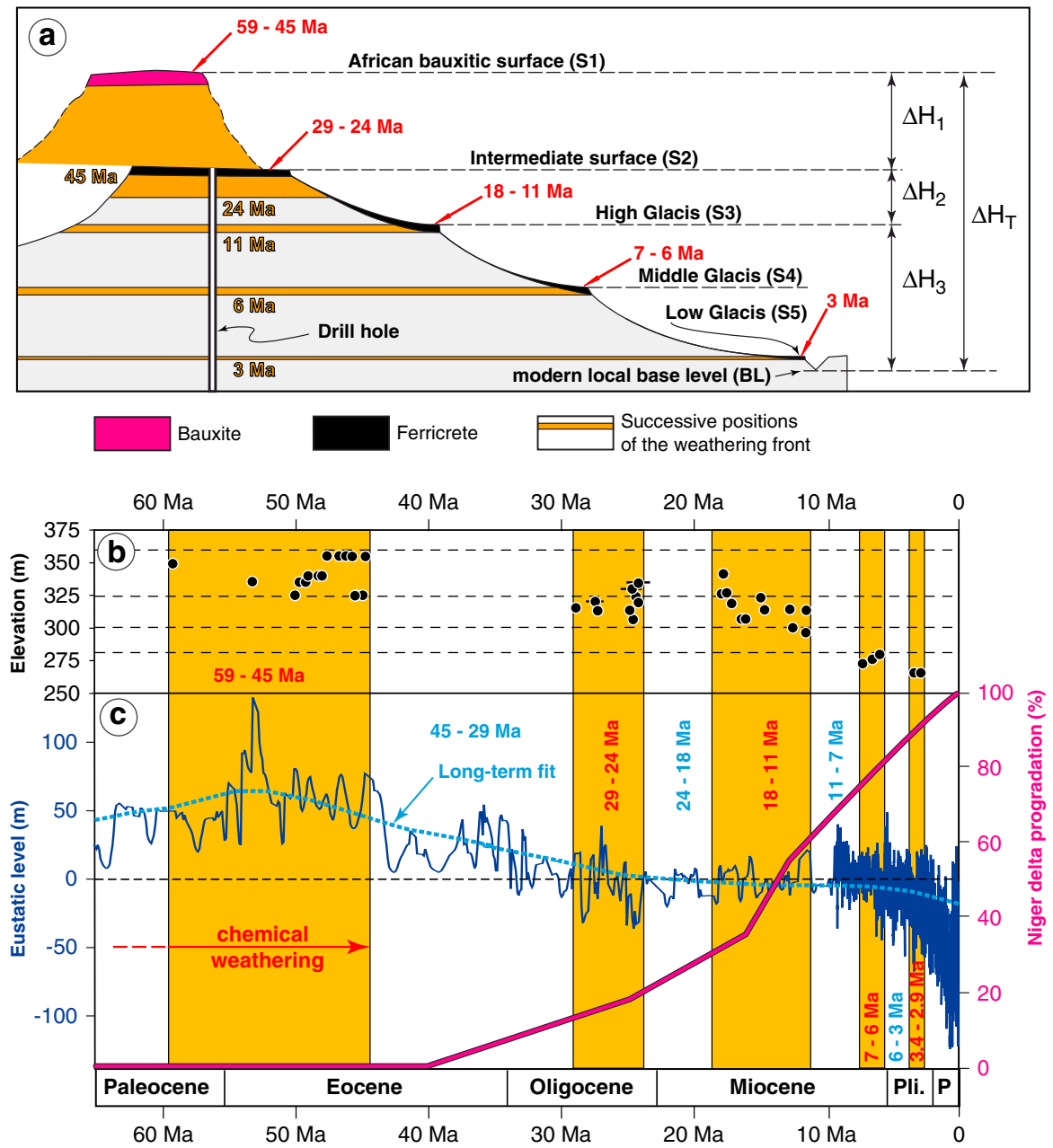

Figure 2. (a) Synthetic denudation chronology framework of the West African morphogenetic sequence as constrained by Ar-Ar geochronology of the Tambao hill Mn ore deposit (location on Figure 1). The bauxitic relictual relief is not seen in Tambao and has been projected from the nearby Aribinda site [see Beauvais et al., 2008]. Ages in red refer to radiometric age groups defining weathering periods that ultimately led to the formation of duricrusts sealing the successive paleolandsurfaces. Ages in orange along the borehole represent the end of the weathering periods that led to establishing the successive alteration fronts connected to the base level of each paleosurface before they were abandoned. These ages are therefore taken as the terminal ages of the successive paleolandsurfaces. (b) Distribution of ${ }^{39} \mathrm{Ar}^{40} \mathrm{Ar}$ plateau ages of $\mathrm{K}-\mathrm{Mn}$ oxides as a function of their elevation (data compiled from Beauvais et al. [2008]). Only error bars exceeding the size of the data points are shown. (c) Eustatic curve (adapted from Miller et al. [2005]) and Niger delta progradation curve (adapted from Séranne [1999]). $\Delta H_{\mathrm{T}}$ - local relief defined by the elevation difference between $\mathrm{S}_{1}$ and today's local base level, BL; $\Delta H_{1}$ - local relief defined by the elevation difference between $\mathrm{S}_{1}$ and $\mathrm{S}_{2} ; \Delta H_{2}$ - local relief defined by the elevation difference between $\mathrm{S}_{2}$ and $\mathrm{S}_{3} ; \Delta H_{3}$ - local relief defined by the elevation difference between $\mathrm{S}_{3}$ and local base level (BL).

to ca. $24 \mathrm{Ma}$, which may be considered as the terminal age of this surface. In turn, the $\mathrm{S}_{2}$ intermediate surface has been dissected from $\sim 24$ to $18 \mathrm{Ma}$ as a consequence of river incision and a switch to drier climate limiting the weathering. A return to weathering conditions from $\sim 18$ to $11 \mathrm{Ma}$ (third age group) achieved shaping of the $S_{3}$ surface that ultimately was sealed by a ferricrete. The Terminal age of the $\mathrm{S}_{3}$ surface is therefore ca. $11 \mathrm{Ma}$. Two morphoclimatic cycles comparable to that having operated from 24 to $11 \mathrm{Ma}$ followed to form and abandon the $\mathrm{S}_{4}$ (middle glacis) and $\mathrm{S}_{5}$ (low glacis) surfaces by ca. 6 and $3 \mathrm{Ma}$, respectively (Figures $2 \mathrm{a}$ and $2 b$ ).

[9] In other words, the lower limits of the radiometric age groups mark the stabilization of the weathering fronts established by the end of each chemical weathering period in connection with the paleolandsurfaces base levels, as well as the abandonment of paleosurfaces by dissection and river 
incision favored by climate switches from humid to seasonally dry (Figures 2a). Therefore, radiometric dating at Tambao indicates that $\mathrm{S}_{1}, \mathrm{~S}_{2}, \mathrm{~S}_{3}, \mathrm{~S}_{4}$, and $\mathrm{S}_{5}$ were abandoned at ca. 45, 24, 11, 6, and $3 \mathrm{Ma}$, respectively, these ages being the terminal ages of these successive paleolandsurfaces (Figure 2a).

\section{Assumptions and Methodology}

[10] The widespread record of $S_{1}, S_{2}$, and $S_{3}$ with consistent geomorphic and regolith petrological and geochemical properties throughout West Africa makes their remnants suitable markers of broadly synchronous past base levels at the scale of the subregion [Grandin and Thiry, 1983; Burke and Gunnell, 2008]. Based on this assumption, we use the denudation chronology model established in Tambao to derive denudation rates defined by the differential elevations of the relicts of $S_{1}, S_{2}, S_{3}$ and local modern river levels at 380 field stations for three erosion periods. The first erosion period is bracketed by the terminal ages of $\mathrm{S}_{1}$ and $\mathrm{S}_{2}$ ( $\sim 45 \mathrm{Ma}$, mid-Eocene, to $\sim 24 \mathrm{Ma}$, end of Oligocene). The second period ( $24-11 \mathrm{Ma}$, early Miocene, base of the Tortonian) corresponds to the erosion phase that ended with the formation of $S_{3}$. The third and last denudation period (ca. 11-0 Ma) starts at the base of the Tortonian with the abandonment of $\mathrm{S}_{3}$.

[11] A field station consists in an area of a few square kilometers comprising residual relief(s) preserving relict(s) of at least one of the three paleosurfaces (Figure 3). At each station, elevations of paleo land surface relicts and local base levels were extracted manually by landscape analysis combining satellite images and the SRTM digital elevation model in the Google Earth software. Three categories of stations are distinguished (see supporting information). ${ }^{1}$ The first category comprises stations that had already been visited, mapped, and interpreted by previous

\footnotetext{
${ }^{1}$ All supporting information may be found in the online version of this article.
}

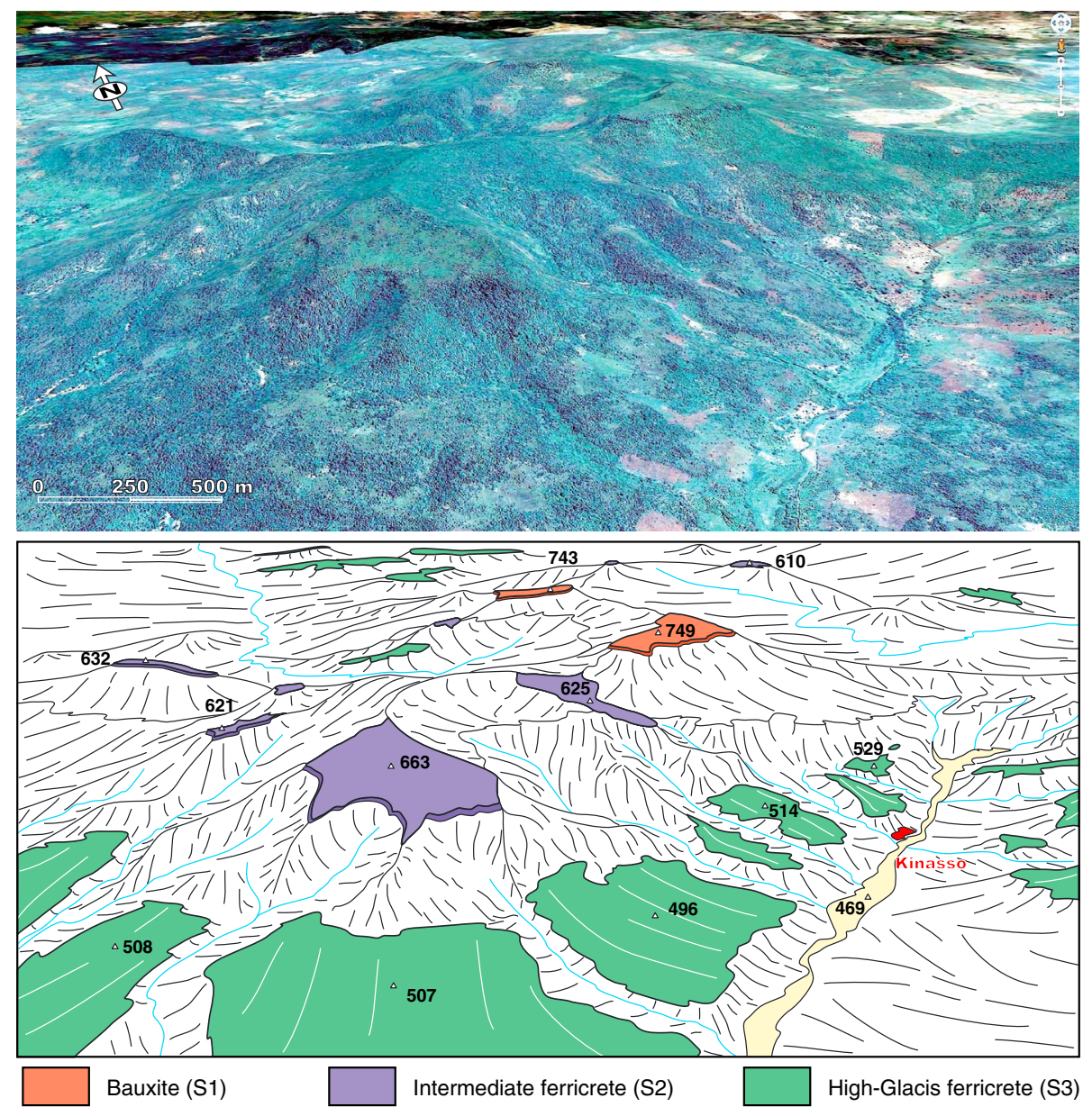

Figure 3. Example of a field station near Kinasso village in Mali (station 98, data repository). The station is located near the southeastern edge of the Banfora plateau and is drained by the uppermost reaches of the Niger watershed (Figure 1). 
authors. The second category comprises stations located in regions we have investigated during field reconnaissance and where the paleolandsurface relicts and regolith covers were identified (Western Guinean rise, Southeastern part of the upper Niger and upper Senegal catchments, Manding Mounts, Niger Basin, upper drainage of the Black Volta, Gondo, and Iullemmeden basins and their margins; Figure 1). Stations of the third category were analyzed and interpreted without ground check, by
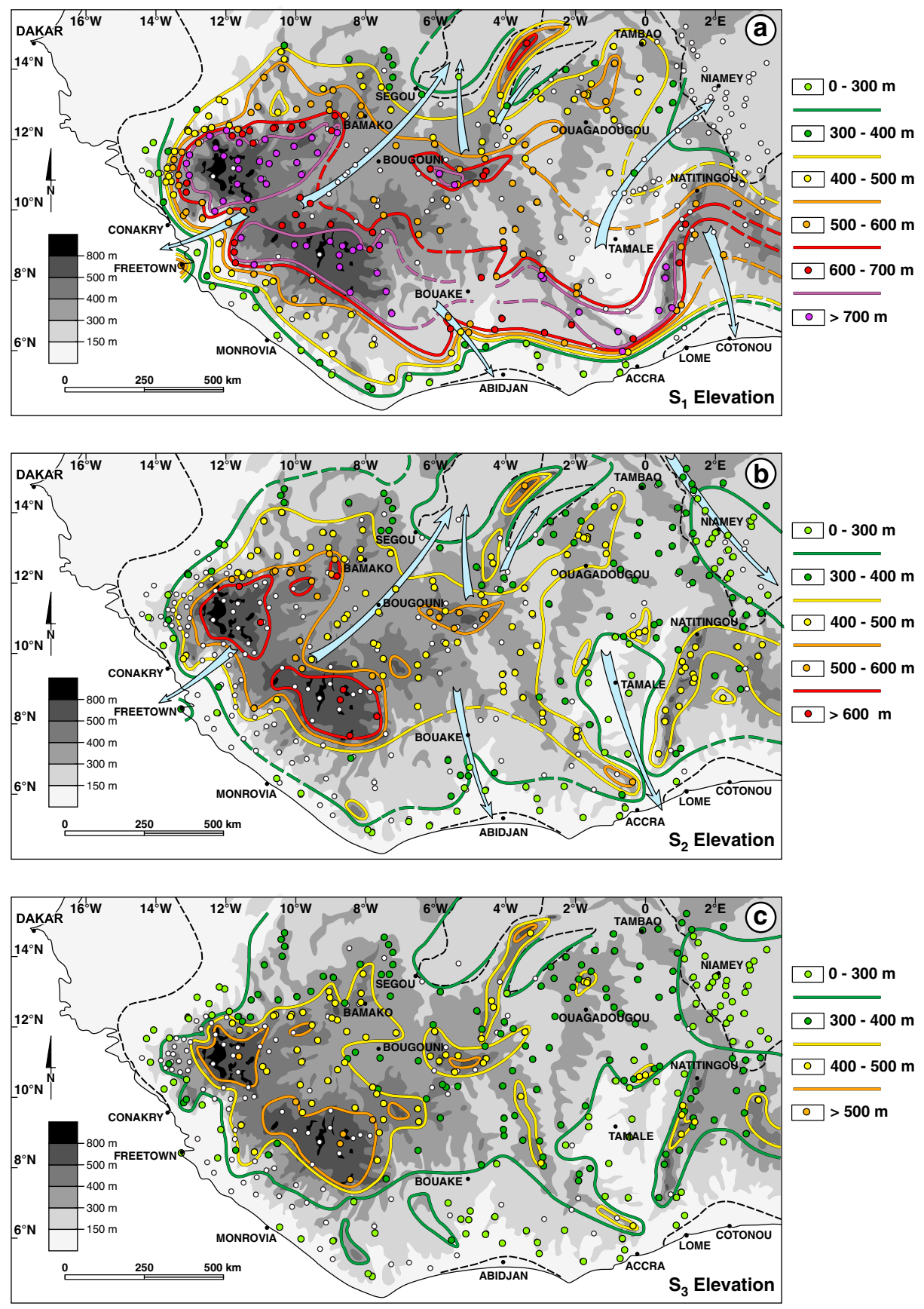

Figure 4. Topography of the successive paleolandsurfaces superimposed on current topography. (a) $\mathrm{S}_{1}$ African bauxitic paleolandsurface, abandoned by $\sim 45 \mathrm{Ma}$ (271 stations). Light blue arrows indicate the main drainage axes. Note that elevated relicts of $S_{1}(>600 \mathrm{~m})$ in large domains of current lower topographies $(<400 \mathrm{~m})$ such as in the Bouaké area is explained by the very small size of bauxitic mesas that cannot be traced on the smoothed current topography, and by the very high differential elevation (200-600 m) between the bauxite and current base level in this area. (b) $S_{2}$ intermediate paleolandsurface, abandoned by $\sim 24$ Ma (257 stations). (c) $S_{3}$ high glacis paleolandsurface shaped by $\sim 11 \mathrm{Ma}$ (293 stations). Open circles are stations where relict(s) of the considered paleolandsurface have not been identified. 
using the same criteria as for other stations combined with the available published descriptions of landscapes and regolith cover of the considered regions.

[12] The error made at measuring the elevation of the local base level is essentially dependent on the resolution of the digital elevation model ( $\sim 5 \mathrm{~m}$ in West Africa; Farr et al. [2007]). The mode of the altitude measured by scanning over the surface of relicts of the different paleosurfaces was taken as representative of the elevation of the paleosurfaces. Considering the SRTM resolution and the minimal elevation of relicts of each surface, which is the maximal estimate of the elevation of paleo-base levels, the error in altitude measurements for $S_{2}$ and $S_{3}$ is estimated at $\sim 20 \mathrm{~m}$, i. e., the half amplitude of the altitudinal range of these two surfaces at each station (e.g., Figure 3). For $S_{1}$ relicts, which have a low relief, the error is estimated at $10 \mathrm{~m}$. The topography of each paleolandsurface is presented in Figure 4 and synthetic cross-sections in Figure 5. Map data were contoured by hand on the basis of elevation classes of the relicts and further constrained on the basis of two principles. First, a paleolandsurface cannot have an elevation lower than the current topography anywhere in the study area (use of the current topography). Second, elevation of a paleolandsurface must be greater than that of the succeeding paleolandsurface at any station (use of stations represented by open circles, Figure 4).

[13] The local relief $(\Delta H)$ deduced from the elevation difference between the relicts of the successive paleolandsurfaces (Figure 2a) is strictly a measurement of the incision. Nonetheless, incision may be considered as a close approximation of denudation on a regional scale at least for the first two erosion periods, because the volume of residual relief abandoned above $\mathrm{S}_{2}$ and $\mathrm{S}_{3}$ is small compared to the areal extent of those paleolandsurfaces (e.g., Figure 3; see also Bishop [1985]). Local reliefs corresponding to the three erosion periods are shown on Figure 6. The corresponding denudation rates, $\operatorname{Dr}$ (Figure 7), are derived from $\Delta H$ and the corresponding denudation time interval. Map data of $\Delta H$ and $D r$ were contoured on the basis of criteria similar to those used for elevation data, by additionally considering constraints provided by successive elevation map contours. Hand-contours for the three data sets were tested and validated by standard numerical contouring procedures. Areas of uncorrelated or patternless data were left uncontoured (e.g., Figure 6c).
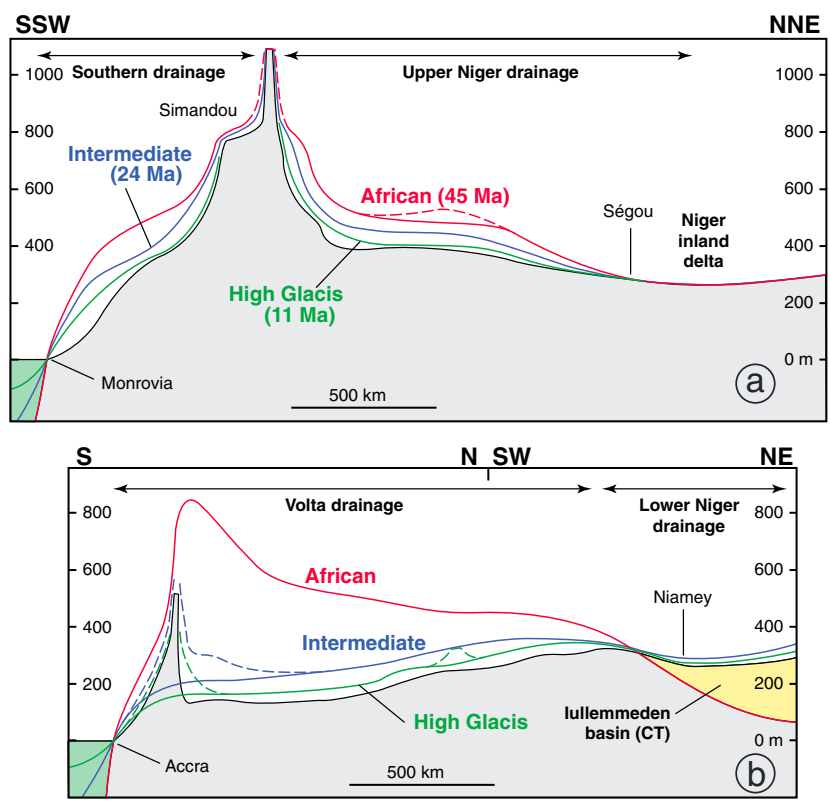

Figure 5. Synthetic cross-sections of the West African marginal upwarp showing the envelopes of the African $\left(\mathrm{S}_{1}\right)$, Intermediate $\left(\mathrm{S}_{2}\right)$, and high glacis $\left(\mathrm{S}_{3}\right)$ paleolandsurfaces, as well as current topography (in grey). The lines of section are located on Figure 1. Dashed lines represent relictual reliefs abandoned above the regional base level at each denudation stage. (a) S1 results from differential fluvial erosion of an old, inherited upwarp now preserved as the Guinean rise. (b) A large eroded volume is defined between $\mathrm{S}_{1}$ and $\mathrm{S}_{2}$, and the $\mathrm{S} 1$ profile mimics that of typical rift-flank uplift models [e.g., Gilchrist and Summerfield, 1990]. This pattern may tentatively suggest denudation-driven flexural isostasy of $S_{1}$ by inland growth of the Volta drainage across the upwarp between 45 and $24 \mathrm{Ma}$. This interpretation would help explain the capture of inland drainage by the Volta across the upwarp, which would have had a lower elevation and was therefore easier to cut through starting at $\sim 45$ Ma before having been uplifted by flexural isostasy. 

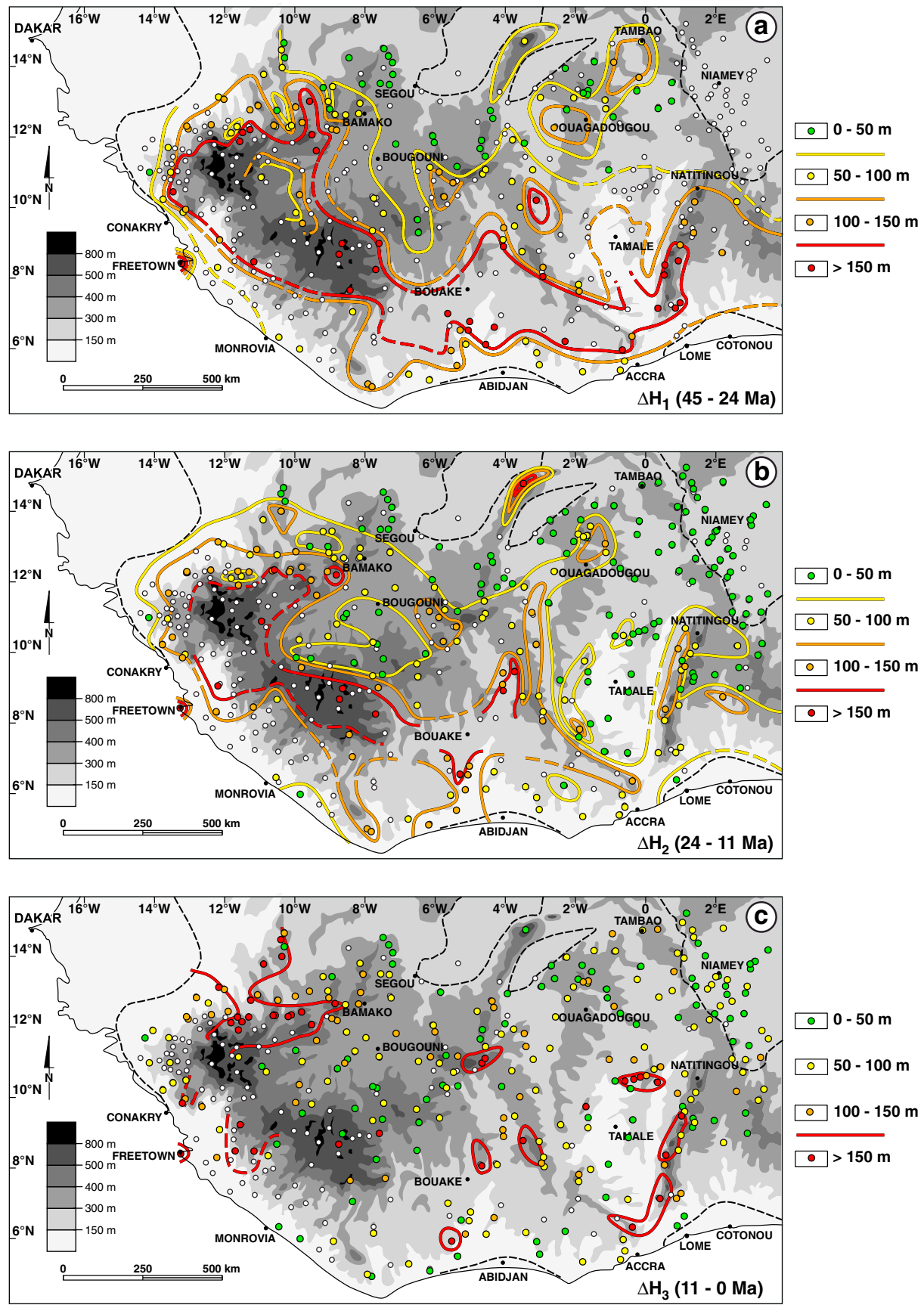

Figure 6. Denudation maps for the three erosion periods superimposed on current topography. (a) 45-24 Ma erosion interval (local relief $\Delta H_{1}=\mathrm{S}_{1}-\mathrm{S}_{2}$ ). (b) 24-11 Ma erosion interval $\Delta H_{2}=\mathrm{S}_{2}-\mathrm{S}_{3}$ ). (c) 11-0 Ma erosion interval $\left(\Delta H_{3}=\mathrm{S}_{3}-\mathrm{BL}\right) . \mathrm{BL}-$ current local base level.

\section{Topography and Denudation Map Patterns}

\subsection{Topography of $S_{1}$ and $S_{2}$ and the $45-24$ Ma Erosion Period}

[14] $\mathrm{S}_{1}$ topography defines a coast-parallel marginal upwarp showing a steep seaward slope and a gentler cratonward slope, which is studded with reliefs such as the Banfora plateau and carved by three main NE-trending valleys leading to the intracratonic sedimentary basins (Figure $4 a$ ). $S_{2}$ topography attests to the general lowering of the upwarp with the maintenance of reliefs inherited from the $\mathrm{S}_{1}$ topographic stage (Figure $4 \mathrm{~b}$ ). The upwarp was largely dissected between 2 and $7^{\circ} \mathrm{W}$ and incised inland Accra as a result of regressive erosion of the Comoé and Volta drainage systems, which led to inland migration of 

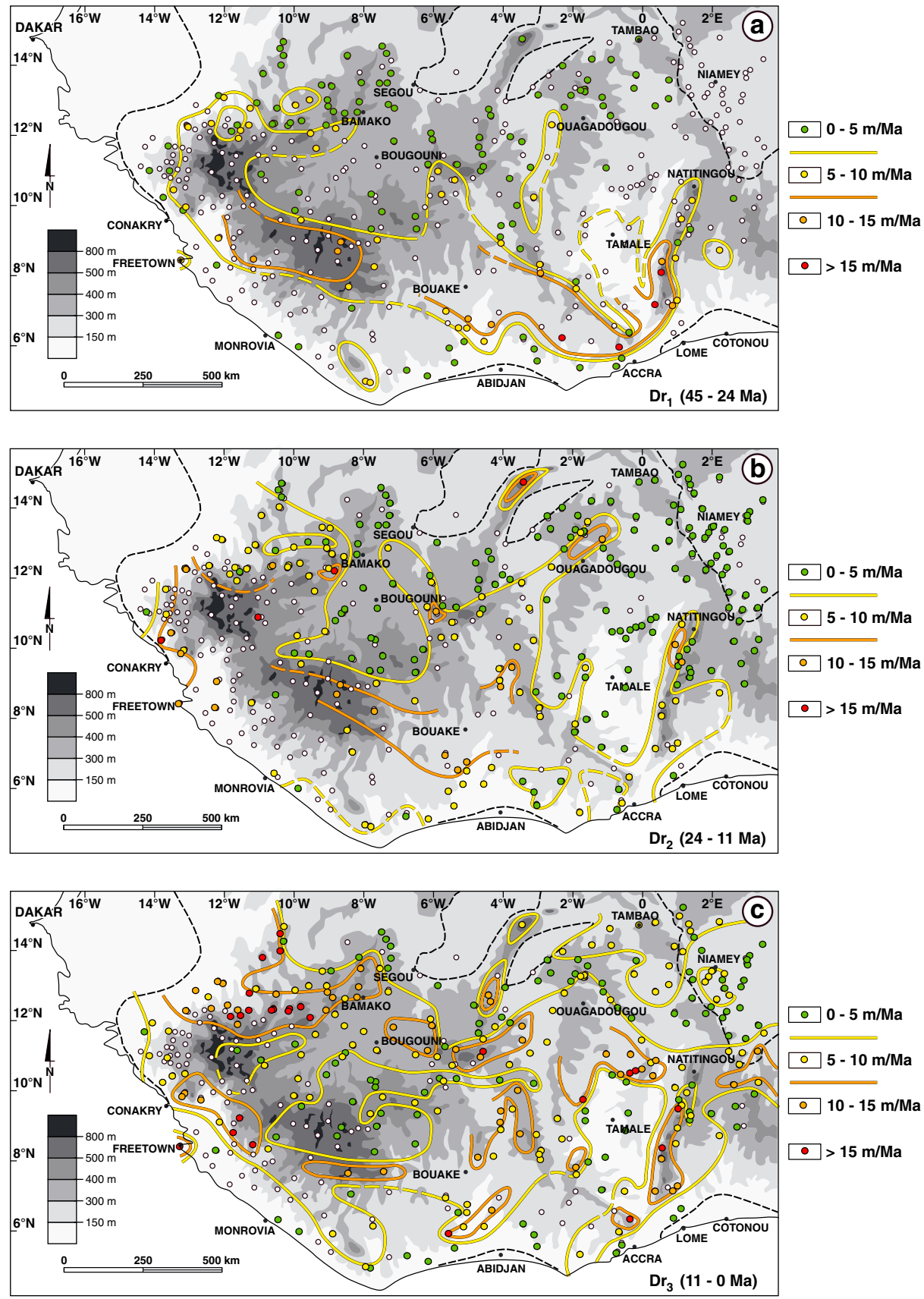

Figure 7. Denudation rates $(D r)$ maps for the three erosion periods superimposed on current topography. (a) $D r_{1}$ (45-24 Ma erosion interval). (b) $D r_{2}$ (24-11 Ma erosion interval). (c) $D r_{3}$ (11-0 Ma erosion interval).

up to $500 \mathrm{~km}$ of the drainage divide (Figures $4 \mathrm{a}, 4 \mathrm{~b}$, and 5). The trough centered on Niamey and aligned parallel to the current Niger River valley attests to the establishment of the modern course of the Niger River by $\sim 24 \mathrm{Ma}$. $\mathrm{S}_{1}$ topography records anomalously high elevation on the Freetown peninsula (Figure $4 \mathrm{a}$ ). $\Delta H_{1}$ and $D r_{1}$ are generally low ( $\leq 100 \mathrm{~m}$ and $<5 \mathrm{~m} \mathrm{Ma}^{-1}$, respectively) with a global pattern that roughly correlates with $\mathrm{S}_{1}$ relief (Figures $6 \mathrm{a}$ and $7 \mathrm{a}$ ).

\subsection{Topography of $S_{3}$ and the 24-11 Ma Erosion Period}

[15] The topographic envelope of $\mathrm{S}_{3}$ mimics today's relief pattern of West Africa (Figures $4 \mathrm{c}$ and 5). $\mathrm{S}_{3}$ topography results from distributed denudation of first-order reliefs inherited from the preceding topographic stages combined with regressive erosion of $\mathrm{S}_{2}$. Regressive erosion was achieved by further inland growth of the Southern drains and the Volta 
watershed (comparison of Figures $4 \mathrm{~b}$ and $4 \mathrm{c}$ ). Moderate local reliefs and denudation rates $\left(\Delta \mathrm{H}_{2}>50 \mathrm{~m}\right.$ and $D r_{2}>5 \mathrm{~m} \mathrm{Ma}^{-1}$ ) roughly correlate with earlyinherited $\mathrm{S}_{1}$ and $\mathrm{S}_{2}$ topographic highs (Figures $4 \mathrm{a}$, $4 \mathrm{~b}, 6 \mathrm{~b}$, and $7 \mathrm{~b})$. Within this pattern, large low denudation anomalies $\left(\Delta H_{2}<50 \mathrm{~m}\right.$ and $\left.D r_{2}<5 \mathrm{~m} \mathrm{Ma}^{-1}\right)$ emerge in the southeastern part of the High Niger watershed and the lower Volta drainage (Figures $6 \mathrm{~b}$ and $7 \mathrm{~b})$.

\subsection{The 11-0 Ma Erosion Period}

[16] Denudation for the last $11 \mathrm{Ma}$ is highly spatially heterogeneous for low and moderate $\Delta H_{3}(<150 \mathrm{~m})$, whereas high $\Delta H_{3}(>150 \mathrm{~m})$ and $D r_{3}\left(>10 \mathrm{~m} \mathrm{Ma}^{-1}\right)$ have a patchy pattern (Figures $6 \mathrm{c}$ and $7 \mathrm{c}$ ). The most prominent high denudation anomaly $\left(D r_{3}>15 \mathrm{~m}\right.$ $\left.\mathrm{Ma}^{-1}\right)$ coincides with the Upper Senegal watershed (northern slope of the Fouta Djalon and Manding Mounts; Figures $6 \mathrm{c}$ and $7 \mathrm{c}$ ). In contrast, large crestal regions of the Guinean rise and the Southeastern Upper Niger drainage coincide with low denudation rates $\left(D r_{3}<5 \mathrm{~m} \mathrm{Ma}^{-1}\right.$; Figure $\left.7 \mathrm{c}\right)$.

\section{Regional Denudation Analysis}

[17] Overall distributions of successive local reliefs are lognormal with a pronounced positive skewness (Figure 8a) and moderate kurtosis (Table 1), reflecting the tendency of paleosurfaces to connect to relicts of the preceding paleosurface on the slope of relictual reliefs (e.g., Figure 3). The mean, median, and mode of the three populations do not exceed $100 \mathrm{~m}$ (ranges of 60-96, 50-80, and 20-100 m, respectively; Table 1). Considering the minimum error of $20 \mathrm{~m}$ on local relief estimates, the three successive populations of local reliefs are virtually undistinguishable (Figure 8b).

[18] The distribution of paleosurface elevations by drainage area appears to consistently correlate with current mean topography of the considered watersheds whatever the denudation interval (Figure 9, left column graphs; see Figure 1). By contrast, the distribution of local reliefs is not clearly distinguished among drainage areas even though SW and $\mathrm{S}$ watersheds appear to have higher $\Delta H_{1}$ and $\Delta H_{2}$ (Figure 9, left column graphs). Scatter plots show a rough correlation between successive local reliefs and paleosurface elevations in each drainage area (Figure 9, right column graphs). Incision is high (data the closest to the $y=x$ limit) but heterogeneous in the SW and S watersheds for each erosion interval (Figure 9, right column graphs). The dependency of $\Delta \mathrm{H}_{2}$ on the elevation of $\mathrm{S}_{2}$ is less pronounced in all drainage areas compared to those of the first and third denudation periods (Figure 9f), reflecting moderate but spatially distributed denudation between 24 and $11 \mathrm{Ma}$ (Figures $6 \mathrm{~b}$ and $7 \mathrm{~b}$ ). Post- $\mathrm{S}_{3}$ incision is the most spatially heterogeneous but also the most efficient within each watershed

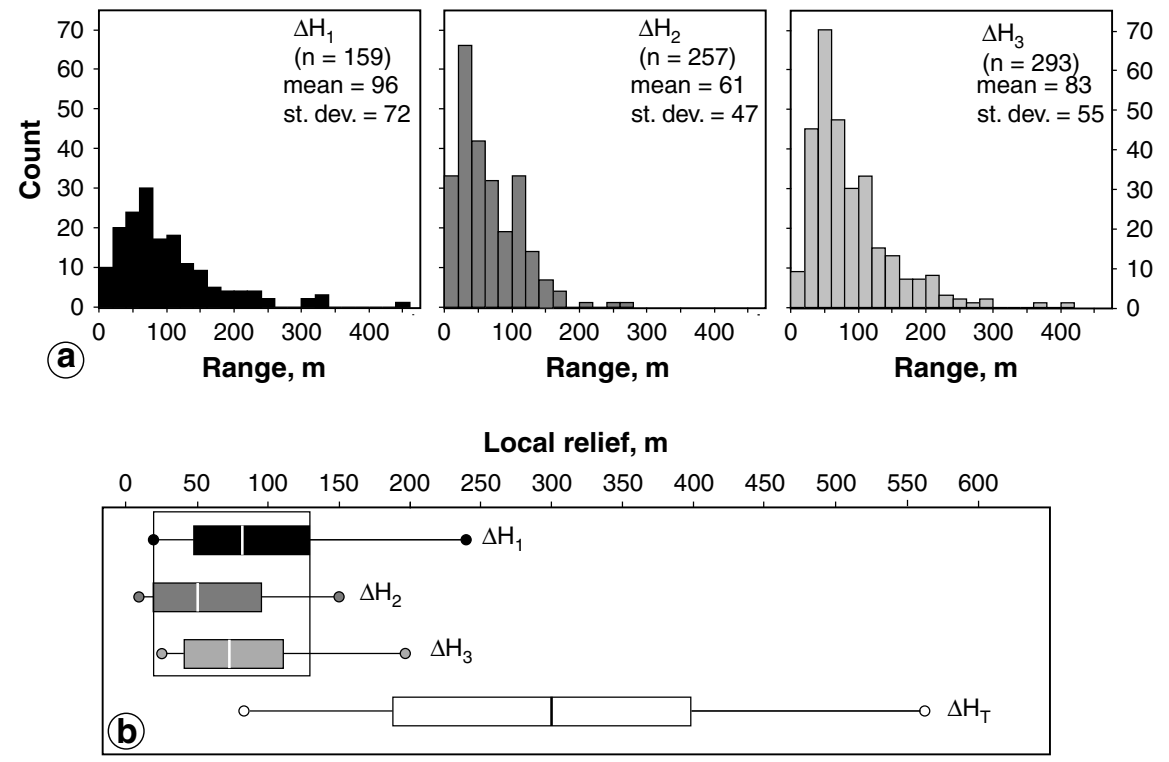

Figure 8. Statistical overview of the denudation data collected over the entire study area. (a) Histograms of the successive local reliefs. (b) Box-and-whisker plots (median, first and third quartiles, $5^{\text {th }}$ and $95^{\text {th }}$ centiles) of the successive local reliefs. 


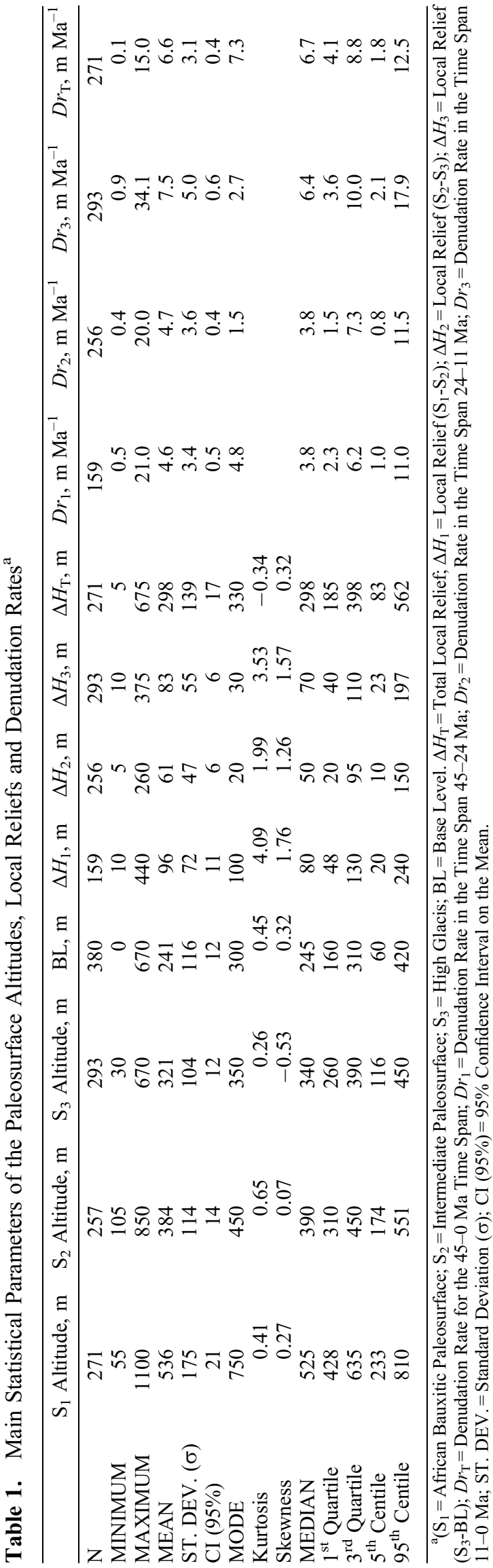

(data globally closer to the $y=x$ limit). In particular, locally enhanced incision is documented in the Senegal and Volta among the long drains (Figure 9i; see also Figures $6 \mathrm{c}$ and $7 \mathrm{c}$ ).

[19] Statistically, no significant differences may be detected in the total local reliefs amongst the drainage areas (Figure 10a). However, type-patterns of $\Delta H_{\mathrm{T}}$ dependency on $\mathrm{S}_{1}$ elevation may be documented from the scatter plot in Figure 10b. Unsurprisingly, the SW and S coastal watersheds are characterized by a high-magnitude heterogeneous incision (Figure 10b) suggestive of numerous knick points. Other drainages show a nearly linear relationship $(y \sim x-300)$ especially over the $300-650 \mathrm{~m} \mathrm{~S}_{1}$ elevation range (Figure $10 \mathrm{~b}$ ), which reflects areas where river slopes tend to mimic that of $S_{1}$. A spread of the data below (Upper Niger), above (Volta), and both below and above (Senegal) the linear relationship points areas characterized respectively by anomalously low, high, and heterogeneous incision of upwarp's reliefs or the upwarp itself. These anomalies were acquired early in the Volta (incision of the marginal upwarp between 45 and $24 \mathrm{Ma}$ ), lately in the Senegal (rejuvenation of the Northwestern slope of the Guinean rise after $11 \mathrm{Ma}$ ), repeatedly in the Upper Niger, and, by extension, in the SW and $\mathrm{S}$ drainages (comparisons of Figures $4 \mathrm{a}, 5,6$, and 10b). Whatever their age, these spatial incision heterogeneities, which attest to differentiated and independent base levels separated by knick-points, primarily reflect adaptation to early topography and reliefs of the upwarp.

[20] Figure 11 explores the dependency of denudation rate $D r_{i}$ on the proportion of incision of a paleosurface of elevation $\mathrm{S}_{i}$ produced by each denudation period creating a local relief $\Delta H_{i} . \Delta H_{i} / \mathrm{S}_{i}$ ratios are often higher for the SW and $\mathrm{S}$ drains compared to all other watersheds for the first two erosion intervals, whereas denudation rates may not be distinguished among the watersheds for any erosion period (Figure 11, left column graphs). Scatter plots reveal a remarkably consistent correlation within and among the watersheds and a large spread of the data for the SW and S drains, which show a pronounced spatial heterogeneity for the last denudation interval (Figure 11, right column graphs). Linear correlations reasonably hold up to 20 to $30 \%$ of relative incision, with the Niger drains deviating the least from this relationship. Slopes of the distributions are comparable for the three erosion intervals (Figure 11, right column graphs). This shows that each erosion period contributed equally to the relative incision of the West African 

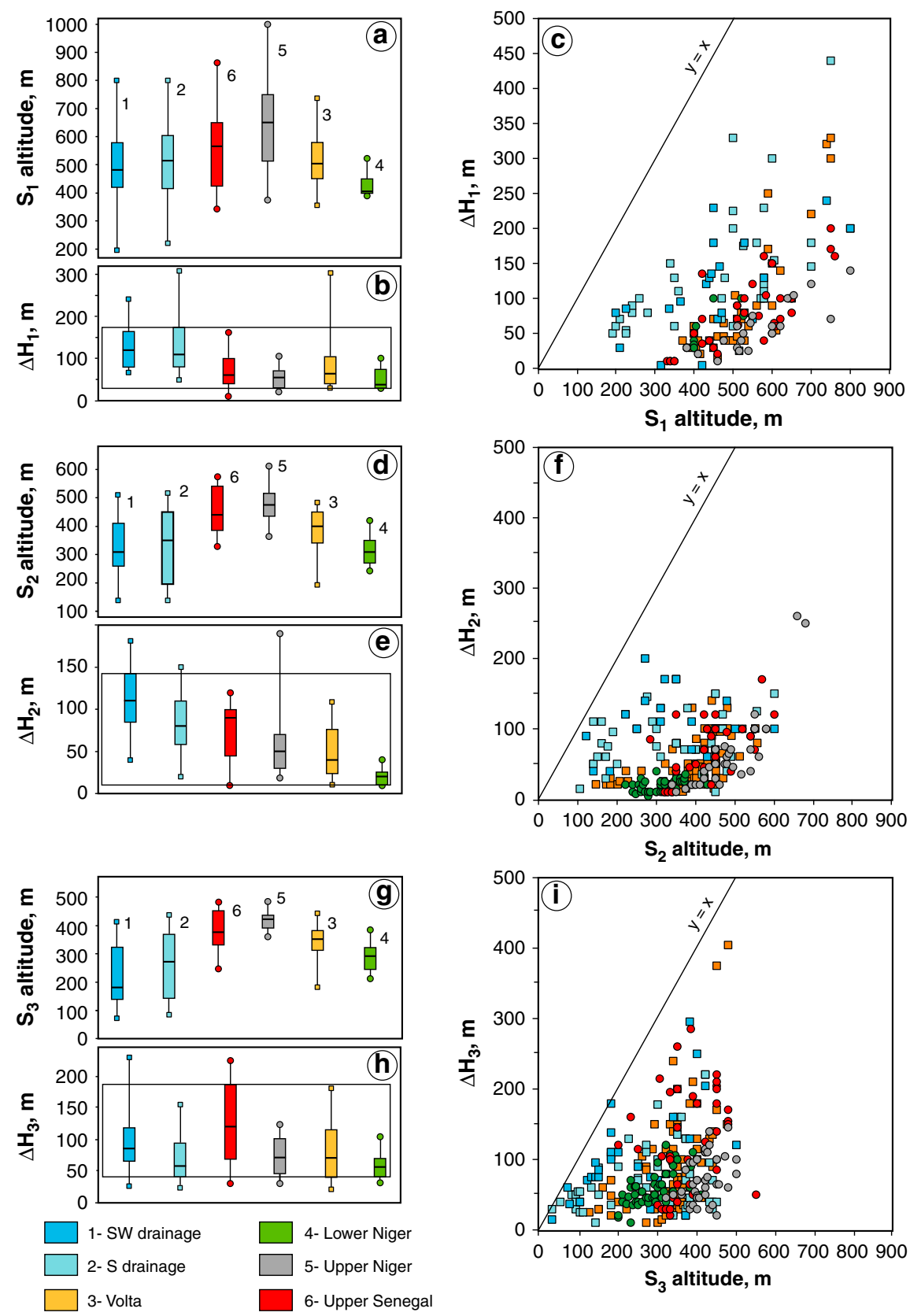

Figure 9. Statistics of the paleosurface altitudes and local reliefs in each subdrainage area for the three considered time spans (45-24, 24-11 and 11-0 Ma). (left) Box-and-whisker plots of paleosurface elevations $\left(\mathrm{S}_{i}\right)$ and corresponding local reliefs $\left(\Delta H_{i}\right)$. (right) Scatter plots of $\Delta H_{i}$ vs. $\mathrm{S}_{i}$ altitude.

topography. Data defining higher slopes correspond to areas where denudation tended toward incision for a given drop in base level (i.e., a given erosion period) as a result of river profile and valley side downwearing, resulting in low-slope graded river profiles. With this respect, the Intermediate erosion period (45-24 Ma; Figure 11c) seems to have been less efficient than the later erosion periods (24-11 Ma and 11-0 Ma; Figures 11f and 11i). This is attested to by the common occurrence of $\mathrm{S}_{2}$ Intermediate surface relicts on relatively steep slopes of residual reliefs [Michel, 1973; Grandin, 1976; Figure 3] indicative of a differentiated landscape of heterogeneous local relief. By contrast, high glacis pediplanation between 24 and $11 \mathrm{Ma}$ and the middle and low glacis pedimentation after $11 \mathrm{Ma}$ would have been more efficient at leveling residual reliefs by valley side downwearing. This contrast may tentatively be interpreted as the capacity for the two later periods 

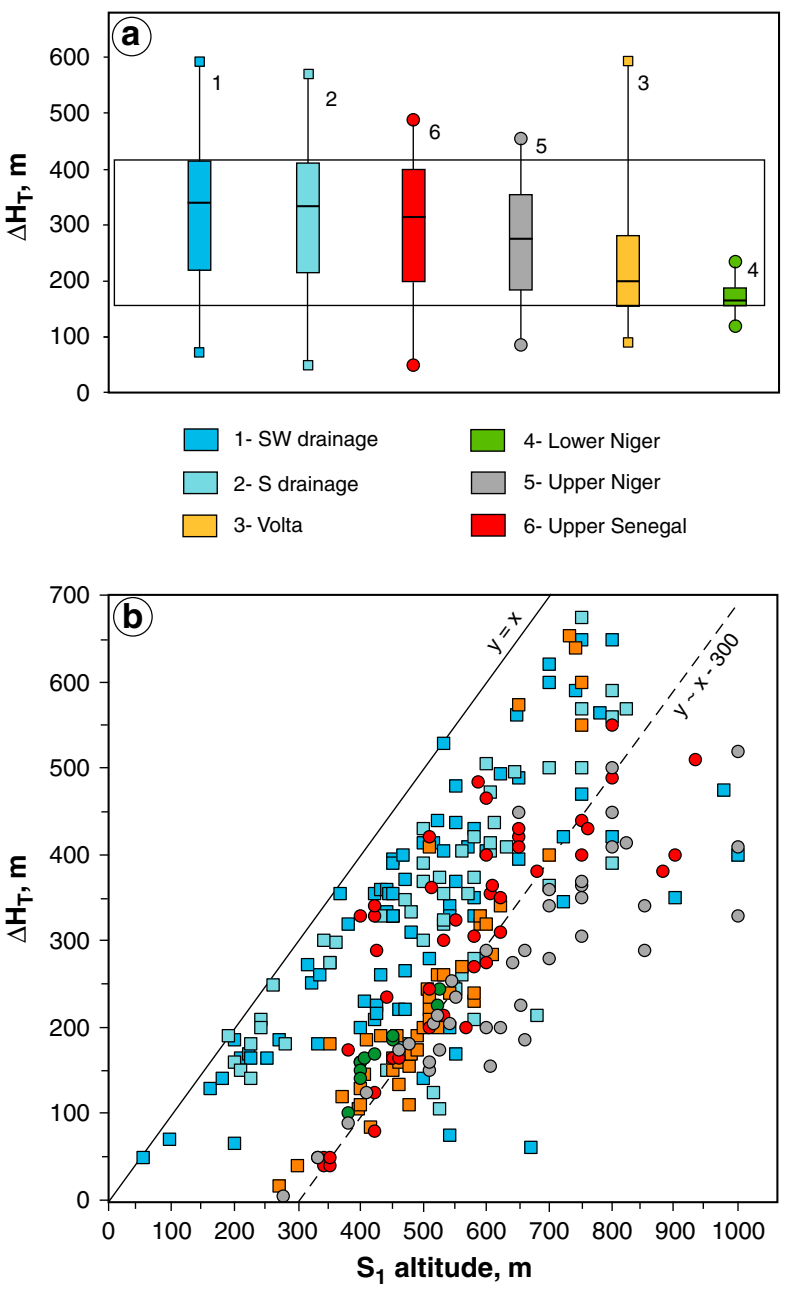

Figure 10. Statistics of the total denudation data of $\mathrm{S}_{1}$ for each subdrainage area of West Africa for the 45-0 Ma time span. (a) Box-and-whisker plot of $\Delta H_{\mathrm{T}}$. (b) Scattered plot of $\Delta H_{\mathrm{T}}$ vs. $\mathrm{S}_{1}$ altitude.

to have removed larger volumes of crust compared to the Intermediate erosion interval for a comparable drop in base level.

[21] Figure 12 is a transposition of the above analysis to the total finite denudation. The SW and $\mathrm{S}$ drains still show relative incisions globally higher than those of the Niger and Volta (Senegal showing intermediate values), whereas total denudation rates are comparable within errors among the watersheds (Figures 12a and 12b). Notwithstanding of the slope of the distribution, the scatter plot (Figure 12c) is remarkably similar to those of Figure 11 for each erosion period. These comparable distributions are further evidence of a predominant initial topographic and relief control onto the early, successive, and total denudation heterogeneity within the main watersheds as well as on a craton scale.

\section{Controls on the Denudation Patterns}

[22] The present analysis reveals a remarkable overall spatial homogeneity of the denudation depths and rates on a cratonic scale over three long-term Cenozoic time slices and between $45 \mathrm{Ma}$ and today. Nonetheless, finer-scale spatial heterogeneities of denudation are documented, which are indicative of spatially differentiated base levels during each denudation period and the entire considered time span. The relief existing at the onset of the considered erosion periods (i.e., at $45 \mathrm{Ma}$ ) exerted a renewed first-order control on denudation heterogeneities [e.g., Gale, 1992], which is further enhanced by protective duricrusts and lithologically controlled escarpments [e.g., Twidale, 1997], reinforcing compartmentalization of erosion. The early and renewed topographic and relief control on the heterogeneity of denudation is typified by rivers draining the seaward slopes of the Guinean Rise (Senegal, SW and S drains), which is likely a topographic relict of the marginal upwarp.

[23] Whatever the considered erosion interval or its duration, typical denudation depths do not exceed $100 \mathrm{~m}$, which is the thickness of a type-bauxitic weathering profile [Bardossy and Aleva, 1990] and more generally of the same order of magnitude as those of typical lateritic weathering mantles (tens of meters). The overall spatial and temporal homogeneity of long-term denudation patterns in West Africa is interpreted as a weathering-limited effect controlled by the regolith thickness available to erosion, of prime importance being the earliest and thickest weathering mantle having accumulated by the end of the bauxitic period.

[24] The present analysis does not allow unequivocally detecting an epeirogenic signal in the subregion with the potential exception of the Freetown Peninsula, where at least part of the denudation may be tentatively linked to isostatic adjustments due to large Mesozoic mafic magmatic intrusions (e.g., McKenzie [1984], for an uplift mechanism). The cross-section in Figure 5a suggests that African surface $S_{1}$ results from fluvial differential erosion of an old, existing upwarp (Figure $4 \mathrm{a}$ ) instead of being an originally flat surface having simply been upwarped. In other words, the African surface is not an unequivocal marker of post-Eocene epeirogeny and the upwarp, such as preserved in the Guinean rise, may as well have existed with a comparable amplitude since at least the Upper Cretaceous, i.e., at a time it already emerged despite the transgression that covered most of the continent [e.g., Sahagian, 1988]. 

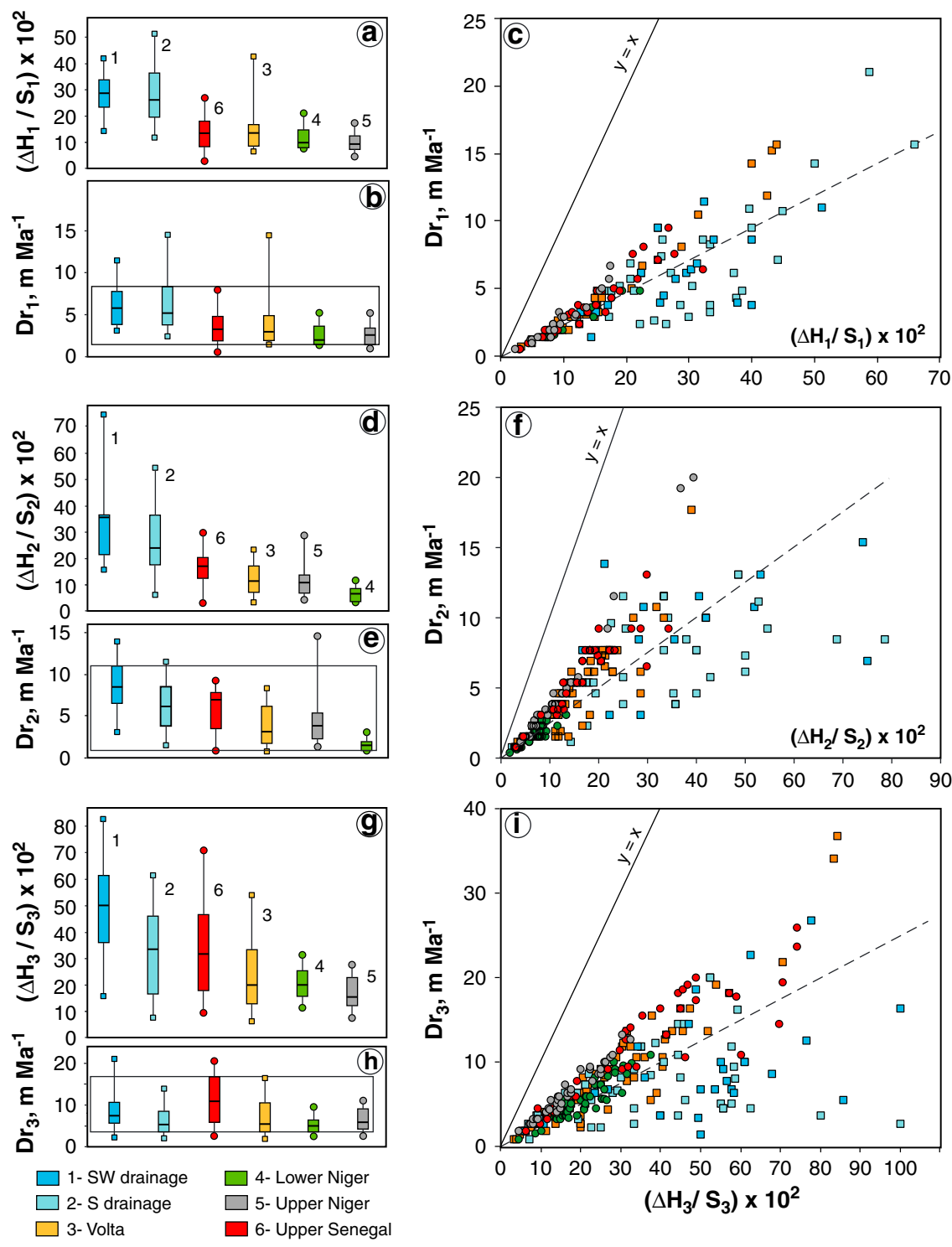

Figure 11. Statistical aspects of the denudation data in each sub-drainage area of West Africa for the three considered time spans (45-24, 24-11 and 11-0 Ma). (left) Box-and-whisker plots of $100 \Delta H_{i} / \mathrm{S}_{i}$ and $D r_{i}$. (right) Scattered plot of $D r_{i}$ vs. $100 \Delta H_{i} / \mathrm{S}_{i}$. The black dashed lines represent the linear best fit for all data.

[25] Our data are compatible with continuous lowering of base levels accompanied by etchplanation (strictly, the stripping of available regolith [Thomas and Summerfield, 1987]) punctuated by relative stabilization periods of enhanced chemical weathering and correlatively inhibited mechanical erosion. In such a model of slow and distributed erosion, positive epeirogeny may not be a necessary condition to generate paleosurface risers. Base levels fall could primarily respond to long-term eustatic sea level fall [e.g., Peulvast et al., 2008] and dominantly climatedriven erosion. Intracratonic base levels could even be relatively insensitive to base level changes at the coast. In any case, duricrusts, as end products of weathering periods of stabilization of weathering fronts, would allow some kind of fossilization of base levels. Within such a framework, the maintenance of spatially differentiated base levels originally and repeatedly controlled by relictual reliefs and knick points would further be favored by slow and distributed, climatically driven denudation that was unable to erase the knick points.

\section{Discussion}

[26] The Niger delta started to build at $\sim 40 \mathrm{Ma}$ (Figure 2c), which is consistent with the establishment of the externally drained Niger River basin between 45 and $29 \mathrm{Ma}$ and with the transition 
from long-lived, dominantly chemical to dominant mechanical erosion processes at $\sim 45 \mathrm{Ma}$. The progradation rate of the delta remained roughly constant since the onset of sedimentation at $\sim 40$ Ma until today (Figure 2c). This indicates that offshore clastic sedimentation was mostly blind to the inferred erosion process changes revealed by Ar-Ar geochronology, supporting the above model of continuous lowering of base levels and correlative denudation. The slight increase in sedimentation rate at $16 \mathrm{Ma}$ (Figure 2c) is recorded worldwide [Clift, 2010] and supports a climate-driven origin for a change in erosional processes. This increase in sedimentation rate could therefore tentatively be assigned to installation of pediplanation-dominated erosion processes in West Africa after $24 \mathrm{Ma}$, especially starting with the later period of high glacis pedimentation between 18 and $11 \mathrm{Ma}$ (Figure $2 \mathrm{c}$ ). The above considerations show that more work is required to better assess the relations between onshore denudation and offshore sedimentation, particularly by working on eroded and deposited volumes within catchments and offshore basins of constrained size.

[27] We compare our denudation rates with those measured over the Cenozoic in cratonic, intracratonic rift, or postrift passive margin settings (Figure 13 and Table 2). The compiled denudation data are obtained on three time scales, i.e., modern $\left(10^{0}-10^{2} \mathrm{yr}\right)$, intermediate $\left(10^{3}-10^{6} \mathrm{yr}\right)$, and long term $\left(10^{6}-10^{8} \mathrm{yr}\right)$. Modern catchment-scale denudation rates are derived from solid and solute fluvial loads in large rivers draining basin areas of ca. $10^{6} \mathrm{~km}^{2}$ [e.g., Milliman and Syvitski, 1992]. Intermediate catchment-scale $\mathrm{Dr}$ may be derived from cosmogenic radionuclides in quartz of river-borne sediments [e.g., Brown et al., 1995; Bierman, 1994] or from concentration of in situ produced cosmogenic radionuclides below exposed landsurfaces [e.g., Brown et al., 1994]. If denudation is significant (typically $>1 \mathrm{~km}$ ), apatite fission-track analysis provides local estimates of long-term $\mathrm{Dr}$ [e.g., Brown et al., 2002]. Figure 13 also compiles long-term $\mathrm{Dr}$ based on differential elevation of paleosurfaces [e.g., Bishop, 1985; Leturmy et al., 2003].

[28] Long-term $\mathrm{Dr}$ defines a narrow range of $\sim 2-20 \mathrm{~m} \mathrm{Ma}{ }^{-1}$, be they locally derived or spatially averaged and whatever the denudation interval considered, with no clear trend as a function of the time scale (Figure 13). This further supports the view of low and spatially distributed long-term denudation in cratons over Cenozoic times. Given the variety of climatic and morphotectonic contexts of the samples, this further indicates that neither
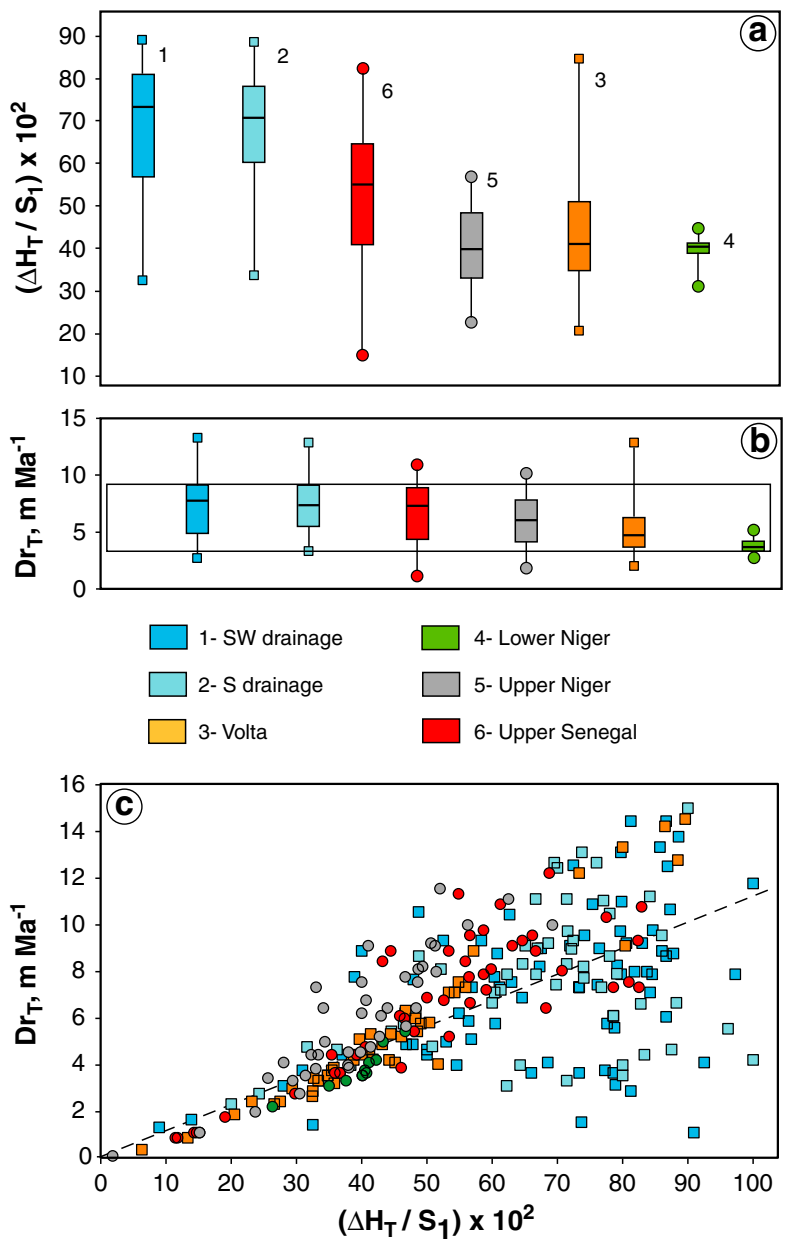

Figure 12. Statistical aspects of the total denudation data in each subdrainage area of West Africa for the 45-0 Ma time span. (a, b) Box-and-whisker plots of $100 \Delta H_{\mathrm{T}} / \mathrm{S}_{1}$ and $D r_{\mathrm{T}}$, respectively. (c) Scatter plot $D r_{\mathrm{T}}$ vs. $100 \Delta H_{\mathrm{T}} / \mathrm{S}_{1}$. The black dashed line represents the linear best fit for all data.

climate nor limited epeirogeny have a decisive influence on the variability of cratonic denudation rates.

[29] Although intermediate and modern denudation rates are considered to be more sensitive to higher frequency/magnitude hydroclimatic events or anthropogenic influences, they do not deviate much from the range defined by long-term $\operatorname{Dr}$ (Figure 13). Outliers could even reflect specific types of forcing, i.e., high rates in South and North America due to the orographic effect of the Andes or to a high runoff controlled by temperate climate, respectively. Our interpretation of this compilation is that the restrained weathering-limited geological denudation rates set the limits to shorter-scale and future denudation rates in cratonic settings. The key limiting factor in this control is the production rate of 


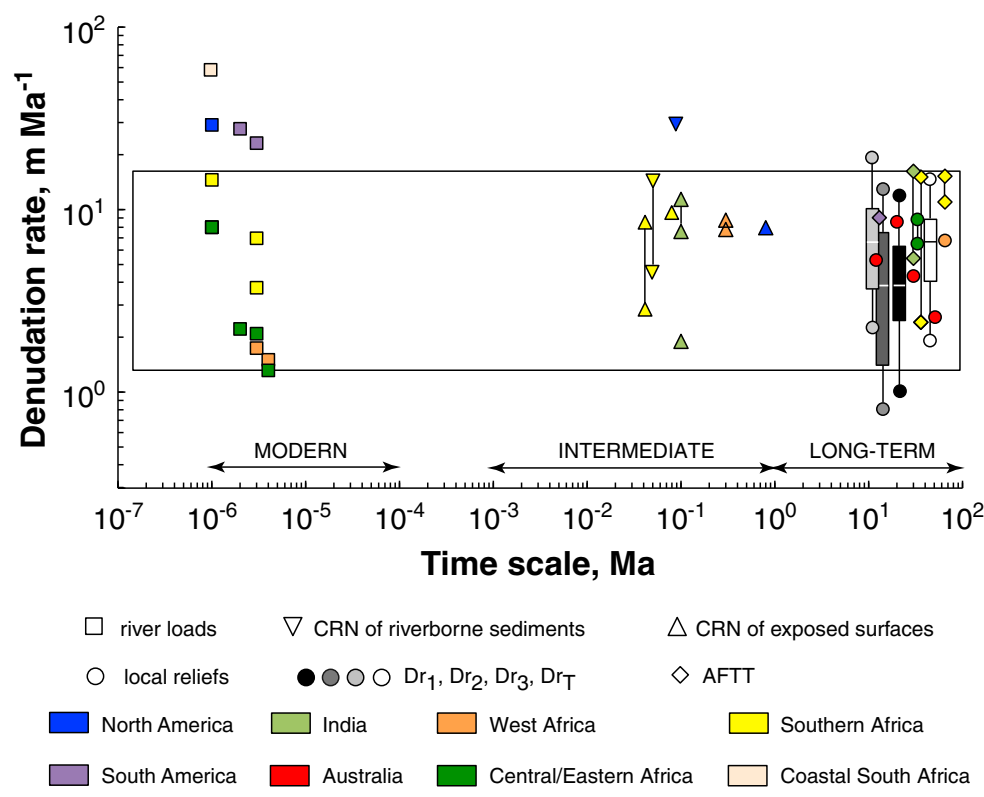

Figure 13. West African denudation rates $D r_{1}, D r_{2}, D r_{3}$, and $D r_{\mathrm{T}}$ (box-and-whisker plots) compared to the compilation of Cenozoic denudation rates obtained over different time scales in geodynamic settings comparable to that of West Africa (Table 2). "Local relief" designates methods comparable to that applied by the present study. CRN - Cosmogenic RadioNuclides; AFTT - Apatite Fission Track Thermochronology. Previous studies considered for this figure provided $D r$ without error bars. Therefore, we use a logarithmic scale to constrain at best possible errors in the data point size. Vertical black lines between two data points represent ranges of $D r$ (see Table 2). Because a direct comparison of denudation rates obtained by different methods through various time intervals may be misleading [Gardner et al., 1987], data were standardized by the scaling function $D r=\Delta H \Delta t^{-0.98}$, where $\Delta t$ is the time interval over which the denudation rate is computed and $\Delta H$ the corresponding denudation depth. The scaling function is defined from the regression equation $\log \Delta H=0.98$ $\log \Delta t+0.856$ (see Gardner et al. [1987] for the details of the method). Standardization has little effect on intermediate and long-term $D r$ but tends to slightly broaden the range of modern $D r$ toward lower values.

regolith or more precisely the thickness of regolith available to stripping as emphasized here in the tropical context. At midlatitudes, the limited production rate or thickness of regolith may be compensated by a higher runoff, whereas the higher regolith thickness in the tropics, most of which being inherited from former weathering periods, may be compensated by the protective effect of duricrusts and dense forest vegetation.

\section{Conclusions}

[30] Cratonic landscapes such as those of West Africa are fundamentally nonequilibrium landscapes evolving on the long term by increasing their relief, which is chiefly influenced by inherited forms. Despite heterogeneities of erosion in the vicinity of those inherited forms, cratonic landscapes are characterized by low and homogeneous denudation rates over most of their surface, whatever the considered time interval in the Cenozoic. We propose this constant and distributed denudation mode to define a steady state cratonic denudation regime. Such regimes operate throughout very large watersheds thanks to the compartmentalization of the base levels generated by relief inheritance, which permits distributed denudation below and above knick points by maintaining typically stepped cratonic river longitudinal profiles [e.g., Wirthmann, 2000]. Steady state cratonic denudation regimes are diffusive in nature but shape landscapes of increasing relief that would be considered as disequilibrium landscapes. Cratonic denudation regimes tend to adapt graded profiles of river reaches comprised between knick points toward equilibrium conditions with climate, more or less independently from a control by coastal base levels.

[31] Steady state cratonic denudation regimes are fundamentally weathering limited. Importantly, positive epeirogeny may not be readily detected in the cratonic denudation pattern and may not be a necessary condition for maintaining steady state cratonic denudation regimes. We suggest that long-term Cenozoic sea level fall and climate variability exert the first-order control onto nearly 
Table 2. Cenozoic Denudation Rates Obtained in Different Regions of the World in Cratonic, Intracratonic Rift or Postrift Continental Margin Settings ${ }^{\mathrm{a}}$

\begin{tabular}{|c|c|c|c|c|c|}
\hline Location & Geodynamic Context & Method & Time Scale & $D r, \mathrm{~m} \mathrm{Ma}^{-1}$ & Source \\
\hline \multicolumn{6}{|l|}{ Eastern North America } \\
\hline Eastern USA & Passive margin & River load & $10^{0}-10^{2}$ & $\sim 40$ & Hack [1979] \\
\hline Southern Appalachians & Passive margin & $\mathrm{CRN}$ & $10^{3}-10^{6}$ & $\sim 30$ & Matmon et al. [2003] \\
\hline Virginia piedmont & Passive margin & CRN & $10^{3}-10^{6}$ & $\sim 8$ & Pavich [1985] \\
\hline \multicolumn{6}{|l|}{ Eastern South America } \\
\hline Amazon River & Cratonic & River load & $10^{0}-10^{2}$ & 93 & $\begin{array}{l}\text { Summerfield and } \\
\text { Hulton [1994] }\end{array}$ \\
\hline Orinoco & Cratonic & River load & $10^{0}-10^{2}$ & 75 & $\begin{array}{l}\text { Summerfield and } \\
\text { Hulton [1994] }\end{array}$ \\
\hline South Parana & Passive margin & AFTT & $10^{7}-10^{8}$ & $\sim 9(13 \mathrm{Ma})$ & Gallagher et al. [1995] \\
\hline \multicolumn{6}{|l|}{ South India } \\
\hline Inselbergs, Mysore plateau & Cratonic & CRN & $10^{3}-10^{6}$ & $\leq 2$ & Gunnell et al. [2007] \\
\hline Lowlands, Mysore plateau & Cratonic/Passive margin & $\mathrm{CRN}$ & $10^{3}-10^{6}$ & $8-12$ & Gunnell et al. [2007] \\
\hline Western Ghats & Passive margin & AFTT & $10^{7}-10^{8}$ & $\sim 5-15(30 \mathrm{Ma})$ & Gunnell et al. [2003] \\
\hline \multicolumn{6}{|l|}{ Southeastern Australia } \\
\hline Muray Darling catchment & Passive margin & local relief & $10^{6}-10^{8}$ & $8(20 \mathrm{Ma})$ & Bishop [1985] \\
\hline Muray Darling catchment & Passive margin & local relief & $10^{6}-10^{8}$ & $4(30 \mathrm{Ma})$ & Bishop [1985] \\
\hline $\begin{array}{l}\text { Bathurst region } \\
\text { (New South Wale) }\end{array}$ & Passive margin & local relief & $10^{6}-10^{8}$ & $\sim 2(51 \mathrm{Ma})$ & Persano et al. [2006] \\
\hline $\begin{array}{l}\text { Bathurst region } \\
\text { (New South Wale) }\end{array}$ & Passive margin & local relief & $10^{6}-10^{8}$ & $\sim 5(12 \mathrm{Ma})$ & Persano et al. [2006] \\
\hline \multicolumn{6}{|l|}{ West Africa } \\
\hline Mormossol area (BF) & Cratonic & $\mathrm{CRN}$ & $10^{3}-10^{6}$ & 3-8 & Brown et al. [1994] \\
\hline Koidu etchplain (SL) & Cratonic/Passive margin & local relief & $10^{6}-10^{8}$ & $\sim 6(65 \mathrm{Ma})$ & Thomas [1994] \\
\hline Niger River & Cratonic/Passive margin & River load & $10^{0}-10^{2}$ & 7 & $\begin{array}{l}\text { Milliman and } \\
\text { Syvitski [1992] }\end{array}$ \\
\hline Niger River & Cratonic & River load & $10^{0}-10^{2}$ & 8 & $\begin{array}{l}\text { Summerfield and } \\
\text { Hulton [1994] }\end{array}$ \\
\hline Milo River & Cratonic & River load & $10^{0}-10^{2}$ & 11 & $\begin{array}{l}\text { Milliman and } \\
\text { Syvitski [1992] }\end{array}$ \\
\hline \multicolumn{6}{|l|}{ Central \& Eastern Africa } \\
\hline Nile river basin & Rift/cratonic & River load & $10^{0}-10^{2}$ & 11 & $\begin{array}{l}\text { Summerfield and } \\
\text { Hulton [1994] }\end{array}$ \\
\hline Zaïre/Congo river & Cratonic/Passive margin & River load & $10^{0}-10^{2}$ & 7 & $\begin{array}{l}\text { Summerfield and } \\
\text { Hulton [1994] }\end{array}$ \\
\hline Southern Kenya & Rift/cratonic & River load & $10^{0}-10^{2}$ & 8.4 & Dunne et al. [1978] \\
\hline Congo river & Cratonic/Passive margin & River load & $10^{0}-10^{2}$ & 6 & Gaillardet et al. [1995] \\
\hline Congo basin & Cratonic/Passive margin & local relief & $10^{6}-10^{8}$ & $6-8(35 \mathrm{Ma})$ & Leturmy et al. [2003] \\
\hline \multicolumn{6}{|l|}{ Southern Africa } \\
\hline Coastal South Africa & Passive margin & River load & $10^{0}-10^{2}$ & $>80$ & Summerfield [1991] \\
\hline Interior South Africa & Cratonic & River load & $10^{0}-10^{2}$ & $<20$ & Summerfield [1991] \\
\hline Orange River & Cratonic/Passive margin & River load & $10^{0}-10^{2}$ & 28 & $\begin{array}{l}\text { Summerfield and } \\
\text { Hulton [1994] }\end{array}$ \\
\hline Zambezi River & Cratonic/Passive margin & River load & $10^{0}-10^{2}$ & 15 & $\begin{array}{l}\text { Summerfield and } \\
\text { Hulton [1994] }\end{array}$ \\
\hline Drakensberg Escarpment & Passive margin & $\mathrm{CRN}$ & $10^{3}-10^{6}$ & 10 & Fleming et al. [1999] \\
\hline Namibian passive margin & Passive margin & CRN & $10^{4}-10^{5}$ & $5-16$ & Bierman and Caffee [2001] \\
\hline Namibian passive margin & Passive margin & CRN & $10^{4}-10^{5}$ & $3-9$ & Bierman and Caffee [2001] \\
\hline Drakensberg Escarpment & Passive margin & AFTT & $10^{7}-10^{8}$ & $\sim 10-14(65 \mathrm{Ma})$ & Brown et al. [2002] \\
\hline Namibian passive margin & Passive margin & AFTT & $10^{7}-10^{8}$ & 2-14 (36 Ma) & Cockburn et al. [2000] \\
\hline
\end{tabular}

a"Local Relief" Designates Methods Comparable to That Applied in the Present Study. "River Load" Designates Methods Based on Solute and Solid Load Measurement at the Outlet of Watersheds. CRN - Cosmogenic RadioNuclides; AFTT - Apatite Fission Track Thermochronology. Values in Brackets in the Dr Column are the Time Intervals Over Which the Denudation Rate has Been Estimated. BF - Burkina Faso; SL - Sierra Leone.

continuous lowering of base levels and its momentary fossilization. An epeirogenic pulse, by increasing regional topographic gradients, would lead to a rupture of the steady state denudation regime and generate denudation depths beyond that of typical regolith thickness and potentially detectable by low-temperature thermochronology. The way in which steady state cratonic denudation regimes 
are expressed in clastic sedimentary fluxes should clearly be the focus of future research.

\section{Acknowledgments}

[32] This work is a contribution of the ANR TopoAfrica (ANR-08-BLAN-0247-02). AB is financially supported by the "Institut de Recherches pour le Développement" (IRD, UMR 161 CEREGE). Initiation of this study owns much to fruitful discussions with, and advises from, G. Grandin and B. Boulangé. We benefited from discussions with D. Rouby and from constructive criticisms and suggestions by M. Séranne and two referees on earlier versions of the manuscript. We thank $\mathrm{Ph}$. Dussouillez for GIS support and C. Cavaré-Hester and A.M. Cousin for their help in finalizing the maps.

\section{References}

Bardossy, G., and G. J. J. Aleva (1990), Lateritic Bauxites, Developments in Economic Geology, p. 27, Elsevier, Amsterdam.

Beaudet, G., R. Coque, P. Michel, and P. Rognon (1977), Altérations tropicales et accumulations ferrugineuses entre la vallée du Niger et les massifs centraux sahariens (Aïr et Hoggar), Z. Geomorph., N. F., 21(3), 297-322.

Beauvais, A., G. Ruffet, O. Hénocque, and F. Colin (2008), Chemical and physical erosion rhythms of the West African Cenozoic morphogenesis: The ${ }^{39} \mathrm{Ar}-{ }^{40} \mathrm{Ar}$ dating of supergene K-Mn oxides, J. Geophys. Res.-Earth surface, 113, F04007, doi:10.1029/2008JF000996.

Bierman, P. R. (1994), Using in situ produced cosmogenic isotopes to estimate rates of landscape evolution: A review from the geomorphic perspective, J. Geophys. Res., 90(B7), 13885-13896.

Bierman, P. R., and M. Caffee (2001), Slow rates of rock surface erosion and sediment production across the Namib desert and escarpment, southern Africa, Am. J. Sci., 301, 326-358.

Bishop, P. (1985), Southeast Australian late Mesozoic and Cenozoic denudation rates: A test for late Tertiary increases in continental denudation, Geology, 13, 479-482.

Bishop, P. (2007), Long-term landscape evolution: linking tectonics and surface processes, Earth Surf. Proc. Landforms, 32, 329-365.

Boulangé, B., and G. Millot (1988), La distribution des bauxites sur le craton Ouest-Africain, Sci. Géol., Bull., 41(1), 113-123.

Boulet, J. (1970), La géomorphologie et les principaux types de sols en Haute-Volta septentrionale, Cah. ORSTOM, série Pédologie, 8, 245-271.

Brown, E. T., D. L. Bourlès, F. Colin, Z. Sanfo, G. M. Raisbeck, and F. Yiou (1994), The development of iron crust lateritic system in Burkina Faso, West Africa, examined with in-situ produced cosmogenic nuclides, Earth Planet. Sci. Lett., 124, 19-33.

Brown, E. T., R. F. Stallard, M. C. Larsen, G. M. Raisbeck, and F. Yiou (1995), Denudation rates determined from the in-situ produced ${ }^{10} \mathrm{Be}$ in the Luquillo experimental forest, PuertoRico, Earth Planet. Sci. Lett., 129, 193-202, doi: 10.1016/ 0012-821X(94)00249-X.

Brown, R. W., M. A. Summerfield, and A. J. W. Gleadow (2002), Denudational history along a transect across the Drakensberg escarpment of southern Africa derived from apatite fission track thermochronology, J. Geophys. Res., 107, B12, 2350, doi:10.1029/2001JB000745

Burke, K., and Y. Gunnell (2008), The African erosion surface: a continental-scale synthesis of geomorphology, tectonics, and environmental change over the past 180 million years, Geol. Soc. Am. Mem., 201, 80.

Chardon, D., V. Chevillotte, A. Beauvais, G. Grandin, and B. Boulangé (2006), Planation, bauxites and epeirogeny: One or two paleosurfaces on the West African margin?, Geomorphology, 82, 273-282, doi:10.1016/j.geomorph.2006.05.008.

Clift, P. D. (2010), Enhanced global continental erosion and exhumation driven by Oligo-Miocene climate change, Geophys. Res. Lett., 37, L09402, doi: 10.1029/2010GL043067.

Cockburn, H. A. P., R. W. Brown, M. A. Summerfield, and M. A. Seidl (2000), Quantifying passive margin denudation and landscape development using a combined fission-track thermochronology and cosmogenic isotope analysis approach, Earth Planet. Sci. Lett., 179, 429-435,

Colin, F., A. Beauvais, G. Ruffet, and O. Hénocque (2005), First ${ }^{40} \mathrm{Ar} /{ }^{39} \mathrm{Ar}$ geochronology of lateritic manganiferous pisolites: Implications for the Palaeogene history of a West African landscape, Earth Planet. Sci. Lett., 238, 172-188, doi:10.1016/j.eps1.2005.06.052.

Dunne, T., W. E. Dietrich, and M. J. Brunengo (1978), Recent and past erosion rates in semi-arid Kenya, Z. Geomorph., N. F. 29, 130-140.

Eschenbrenner, V., and G. Grandin (1970), La séquence des cuirasses et ses différenciations entre Agnibulekrou (Côte d'Ivoire) et Diebougou (Haute Volta), Cah. ORSTOM, série Géologie, II(2), 205-245.

Fairbridge, R. W., and C. W. Finkl (1980), Cratonic erosional unconformities and peneplains, J. Geol., 88, 69-86.

Farr, T. G., et al. (2007), The shuttle radar topography mission, Rev. Geophys., 45, RG2004.

Fleming, A., M. A. Summerfield, J. O. Stone, L. K. Fifield, and R. G. Cresswell (1999), Denudation rates for the southern Drakensberg escarpment, SE Africa, derived from in-situproduced cosmogenic ${ }^{36} \mathrm{Cl}$, initial results, J. Geol. Soc. Lond., 209, 156-212.

Gaillardet, J., B. Dupré, and C. J. Allègre (1995), A global chemical budget applied to the Congo basin rivers: Erosion rates and continental crust composition, Geochim. Cosmochim. Acta, 59, 3469- 3485.

Gale, S. J. (1992), Long-term landscape evolution in Australia, Earth Surf. Proc. Landforms, 17(4), 323-343.

Gallagher, K., C. J. Hawkesworth, and M. S. M. Mantovani (1995), Denudation, fission track analysis and the longterm evolution of passive margin topography: application to the southeast Brazilian margin, J. S. Am. Earth Sci., $8(1), 65-77$.

Gardner, T. W., D. W. Jorgensen, C. Schuman, and C. Lemieux (1987), Geomorphic and tectonic process rates: effects of measured time interval, Geology, 15, 259-261.

Gilchrist, A. R., and M. A. Summerfield (1990), Differential denudation and flexural isostasy in formation of rifted margin upwarps, Nature, 346, 739-742.

Grandin, G. (1976), Aplanissements cuirassés et enrichissement des gisements de manganèse dans quelques régions d'Afrique de l'Ouest, Mém. ORSTOM, 82, 275.

Grandin, G., and M. Thiry (1983), Les grandes surfaces continentales tertiaires des régions chaudes. Succession des types d'altération, Cah. ORSTOM, série Géologie, 13, 3-18. Gunnell, Y., K. Gallagher, A. Carter, M. Widdowson, and A. J. Hurford (2003), Denudation history of the continental margin of western peninsular India since the early Mesozoic reconciling apatite fission-track data with geomorphology, Earth 
Planet. Sci. Lett., 215, 187-201, doi:10.1016/S0012-821X (03)00380-7.

Gunnell, Y., R. Braucher, D. Bourlès, and G. André (2007), Quantitative and qualitative insights into bedrock landform erosion on the South Indian craton using cosmogenic nuclides and apatite fission tracks, Geol. Soc. Am. Bull., 119, 576-585.

Hack, J. T. (1979), Rock control and tectonism - Their importance in shaping the Appalachian Highlands, U. S. Geol. Surv. Prof. Pap., 1126-B, B1-B17.

Hénocque, O., G. Ruffet, F. Colin, and G. Féraud (1998), ${ }^{40} \mathrm{Ar} /{ }^{39} \mathrm{Ar}$ dating of West African lateritic cryptomelanes, Geochim. Cosmochim. Acta, 62(16), 2739-2756, doi:10.1016/ S0016-7073(98)00185-9.

Lang, J., C. Kogbe, K. Alidou, A. Alzouma, D. Dubois, A. Houessou, and J. Trichet (1986), Le sidérolithique du Tertaire Ouest-africain et le concept de Continental Terminal, Bull. Soc. Géol. France, 8(4), 605-622.

Leturmy, P., F. Lucazeau, and F. Brigaud (2003), Dynamic interactions between the Gulf of Guinea passive margin and the Congo River drainage basin: 1. Morphology and mass balance, J. Geophys. Res., 108(B8), 2383, doi:10.1029/ $2002 J B 001927$.

McKenzie, D. (1984), A possible mechanism for epeirogenic uplift, Nature, 307, 616-618.

Matmon, A., P. R. Bierman, J. Larsen, S. Southworth, M. Pavich, and M. Caffee (2003), Temporally and spatially uniform rates of erosion in the southern Appalachian Great Smoky Mountains, Geology, 31, 155-158.

Michel, P. (1973), Les Bassins des fleuves Sénégal et Gambie : étude géomorphologique, Mém. ORSTOM, 63, 1-752.

Miller, K. G., M. A. Kominz, J. V. Browning, J. D. Wright, G. S. Mountain, M. E. Katz, P. J. Sugaman, B. S. Cramer, N. Christie-Blick, and S. F. Pekar (2005), The Phanerozoic record of global sea-level change, Science, 310, 1293-1298.

Milliman, J. D., and J. P. M. Syvitski (1992), Geomorphic/ tectonic control of sediment discharge to the ocean: The importance of small mountainous rivers, J. Geol., 100, 525-544.

Molnar P. (2004), Late Cenozoic increases in accumulation rates of terrestrial sediments: How might climate change have affected erosion rates?, Ann. Rev. Earth Planet. Sci., 32, 67-89, doi:10.1146/annurev.earth.32.091002.143456.

Pavich, M. J. (1985), Appalachian piedmont morphogenesis: weathering, erosion, and Cenozoic uplift, in Tectonic
Geomorphology, edited by M. Morisawa and J. T. Hack, George, Allen and Unwin, London, pp. 27-51.

Persano, C., P. Bishop, and F. M. Stuart (2006), Apatite (U-Th)/He age constraints on the Mesozoic and Cenozoic evolution of the Bathurst region, New South Wales: evidence for antiquity of the continental drainage divide along a passive margin, Aust. J. Earth Sci., 53, 1041-1050.

Peulvast, J.-P., V. Claudino Sales, F. Bétard, and Y. Gunnell (2008), Low post-Cenomanian denudation depths across the Brazilian Northeast: Implications for long-term landscape evolution at a transform continental margin, Global Planet. Change, 62, 39-60.

Prasad, G. (1983), A review of the early Tertiary bauxite events in South America, Africa and India, J. Afr. Earth Sci., 1, 305-313.

Sahagian, D. (1988), Epeirogenic motions of Africa as inferred from Cretaceous shoreline deposits, Tectonics, 7(1), 125-138.

Séranne, M. (1999), Early Oligocene stratigraphy turnover on the West Africa continental margin: a signature of the Tertiary greenhouse-to-icehouse transition?, Terra Nova, 11, 135-140.

Summerfield, M. A. (1991), Subaerial denudation of passive margins: regional elevation versus local relief models, Earth Planet. Sci. Lett., 102, 460-469.

Summerfield, M. A., and N. J. Hulton (1994), Natural controls of fluvial denudation rates in major world drainage basins, J. Geophys. Res., 99(B7), 13,871-13,883.

Tardy, Y., and C. Roquin (1998), Dérive des continents, paléoclimats et altérations tropicales, Bur. Rech. Géol., Min., Orléans, France.

Thomas, M. F. (1994), Geomorphology in the Tropics. A Study of Weathering and Denudation in Low Latitudes, Wiley \& Sons, New York.

Thomas, M. F., and M. A. Summerfield (1987), Long-term landform development: key themes and research problems, in International Geomorphology 1986, part II, edited by V. Gardiner, pp. 935-956, Wiley \& Sons, New York.

Twidale, C. R. (1997), The great age of some Australian landforms: examples of, and possible explanations for landscape longevity, in Paleosurfaces: Recognition, Reconstruction and Palaeoenvironmental Interpretation, edited by M. Widdowson, Geol. Soc. Spec. Publ., 120, 13-23, Geological Society of London, Bath.

Wirthmann, A. (2000), Geomorphology of the Tropics, Springer-Verlag, Berlin. 